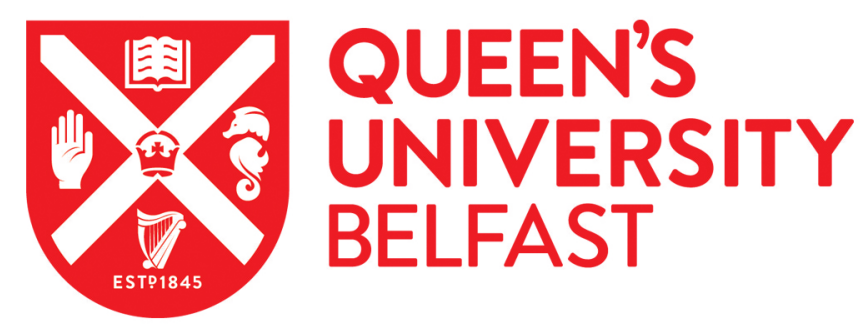

\title{
A Systematic Review of Applied Behavior Analytic Interventions for Children with Autism in Mainland China
}

\author{
Liao, Y., Dillenburger, K., He, W., Xu, Y., \& Cai, H. (2020). A Systematic Review of Applied Behavior Analytic \\ Interventions for Children with Autism in Mainland China. Review Journal of Autism and Developmental \\ Disorders. https://doi.org/10.1007/s40489-020-00196-w
}

\section{Published in:}

Review Journal of Autism and Developmental Disorders

\section{Document Version:}

Peer reviewed version

Queen's University Belfast - Research Portal:

Link to publication record in Queen's University Belfast Research Portal

\section{Publisher rights}

(C) 2020 Springer Science+Business Media, LLC, part of Springer Nature.

This work is made available online in accordance with the publisher's policies. Please refer to any applicable terms of use of the publisher.

\section{General rights}

Copyright for the publications made accessible via the Queen's University Belfast Research Portal is retained by the author(s) and / or other copyright owners and it is a condition of accessing these publications that users recognise and abide by the legal requirements associated with these rights.

Take down policy

The Research Portal is Queen's institutional repository that provides access to Queen's research output. Every effort has been made to ensure that content in the Research Portal does not infringe any person's rights, or applicable UK laws. If you discover content in the Research Portal that you believe breaches copyright or violates any law, please contact openaccess@qub.ac.uk. 


\section{Systematic reviews of applied behavior analytic interventions for children diagnosed with autism in mainland China}

Authors: Yini Liao ${ }^{1}$, Karola Dillenburger ${ }^{2}$, Wei He${ }^{1}$, Ying $\mathrm{Xu}^{1} \&$ Hongwei Cai $^{1}$

Accepted for publication 6 January 2020 in

Review Journal of Autism and Developmental Disorders

1. Dr Yini Liao, PhD. Department of Psychology, Sun Yat-sen University, Guangzhou, China.Email: liaoyn3@mail.sysu.edu.cn

2. Prof. Karola Dillenburger, PhD, BCBA-D. Center for Behavior Analysis, School of Social Sciences, Education, and Social Work, Queen's University Belfast, Belfast, UK. Email: k.dillenburger@qub.ac.uk

Author of Correspondence: Correspondence should be addressed to Dr Yini Liao, liaoyn3@mail.sysu.edu.cn; Tel: +86(0)2039349895; Address: 132 Waihuan Dong Road, Higher Education Mega Centre, Guangzhou, 510006, China

\footnotetext{
Abstract

Applied Behavior Analysis (ABA)-based interventions, particularly when utilised to support children diagnosed with Autism Spectrum Disorders (ASD), are typically conducted in Western societies and published in the English language. However, little is known about the utilisation of applied behavior analysis for children with autism in
} 
China. This paper provides systematic reviews of English and Chinese studies conducted in Mainland China. The search generated 33 articles that met the selection criteria. The results suggest that Chinese ABA-based programmes appear to be equally as effective as programmes elsewhere. One of the key differences of the Chinese programmes was the strong emphasis on parental involvement. The review also revealed the wide use of non-behavioral eclectic methods and the lack of well-designed experimental studies in Chinese studies. The implications of these findings for future researchers and practitioners are discussed.

Key words: Review; ABA; autism spectrum disorder; ASD; China

Funding: The project was supported by the Natural Science Foundation of Guangdong Province, China (Grant No. 2018A030310094). The first author was funded by Queen's University Belfast/China Scholarship Council PhD studentship and the Great BritainChina Educational Trust scholarship under the supervision of the second author.

Acknowledgement: Authors would like to thank Dr Yi Mou's, from Department of Psychology, Sun Yat-sen University, suggestions on the final draft of this paper.

Conflict of Interest: The authors declare that they have no conflict of interest. 
Autism Spectrum Disorder (ASD) is a neurodevelopmental disorder that is diagnosed when individuals display difficulties in social communication and/or restricted, ritualized behaviors over a prolonged period (American Psychiatric Association, APA, 2013). Various treatment approaches have been developed to help children with autism and their families. Nearly all evidence-based internventions (Eikeseth, Hayward, Gale, Gitlesen, \& Eldevik, 2009; Howard, Stanislaw, Green, Sparkman, \& Cohen, 2014; Smith, Hayward, Gale, Eikeseth, \& Klintwall, 2019) are based on the application of the scientific discipline of behavior analysis (Baer, 1962; Baer, Wolf, \& Risley, 1968, 1987; Skinner, 1988). ABAbased interventions for children diagnosed with autism were originally developed in the United Stated (Lovaas, 1987, Smith, 2001; United States Surgeon General, 1999) and are now used across the world (Eikeseth, Klintwall, Jahr, and Karlsson, 2012; Liao, Dillenburger \& Buchanan, 2018; Love, Carr, Almason, \& Petursdottir, 2009; Peters-Scheffer, Didden, Mulders, \& Korzilius, 2010). In applied behaviour analysis (ABA), data collection and analysis are key elements (Cooper, Heron, \& Heward, 2007), that typically are demostrated through intra-subject comarisons, using single-system designs (Hitchcock, Kratochwill, \& Chezan, 2015; Institute of Education Sciences, IES, 2017; Kratochwill et al., 2013). By visually analyzing the graphed data in different phases of the intervention, researchers and clinicians assess the effects of the intervention and, if necessary, adjust interventions in a timely and individually tailored manner.

Early Intensive Behavioral Interventions (EIBI) are commonly part of the comprehensive ABA-based treatment package for young children with autism, that include procedures, such as Discrete Trial Teaching (DTT) and Natural Environment Training (NET) (Lovaas, 1987; Orinstein et al., 2014; Smith, Groen, \& Wynn, 2000), amongst others. EIBI has been used to increase many socially significant behaviors, including language and communication skills, life skills, cognitive and functional behaviors (Fein et al., 2013; Lovaas, 1987; Reichow, Barton, Boyd, \& Hume, 2012; Reichow \& Wolery, 2009; Wong et al., 2015).

ABA-based interventions have been used in developed as well as developing countires. In China, the first case of autism was recognized in 1982 (Tao, 1987), much later than in the USA where early cases were reported by Leo Kanner in 1938 (Kanner, 1943) or in Austria where first cases were reported by Hans Asperger in 1944 (Translated by Frith, 1991). It was not until 1995 that autism was included in the second edition of the Chinese 
Category of Mental Disorders (Psychosis Branch of Chinese Medical Association \& Brain Hospital of Nanjing Medical University, 1995).

Partly due to the relatively late identification of autism as a stand-alone diagnostic category, studies of prevalence rates are still being accumulated while existing data of prevalence rate are not consistent across existing studies. For example, Jin, Yang, Liu, Huang, \& Jin (2018) conducted a cross-sectional study among 74,252 children aged between 3 and 12 years old in Shanghai, and found that 8.3 in every 10,000 children were diagnosed with autism according to DSM-5. Yang et al. (2015) surveyed 15,200 preschool children in a city in South China, and reported 260 per 10,000 of the children had a high risk of autism and 400 per 10,000 were suspected to have autism. Guo (2004) reported only 5 children with autism and co-occurring intellectual disability among 3,606 children (2-6 year olds) in a city in North China. Other studies reported that the pooled prevalence of autism in mainland China is estimated 39.23 per 10,000 children aged between 1.6 and 8 years old (Wang et al., 2018) and 70 per 10,000 children aged between 6 and 12 years old (Zhou et al., 2018).

Although autism prevalence rates vary signficantly across Chinese studies, they are generally lower than that in Western countries. For example, in the USA, 241 in 10,000 children were diagnosed with autism (Xu, Strathearn, Liu, \& Bao, 2018) and in the UK, 350 in 10,000 children were reported to have autism in a sample of over 15,000 families (Dillenburger, Jordan, McKerr, \& Keenan, 2015). The reasons for the relatively low prevalence of autism reported in China are unclear, but they are likely related to the relatively late recognition of autism as a stand-along diagnostic category. If this indeed were to be the case, future studies likely will report prevalence rates be more aligned with Western figures.

Given the huge population of China, there are a very significant number of Chinese children with this neurodevelopmental disorder (Sun et al., 2013). Not surprisingly, many organisations that aim to support these children have been established since 1990s (McCabe $\&$ Tian, 2001). There now are approximately 1,000 autism training centres in mainland China that use various intervention approaches (Zhou et al., 2014). The first training organization in mainland China, Beijing Stars and Rain, was established in 1993, and it was also the first one that introduced ABA-based interventions into their program (Guo, 2006; McCabe \& Tian, 2001; Wen, 2014; Zhou et al., 2014). Subsequently, therapists, researchers, and government policy makers together promoted ABA-based approaches and make them publically available (Zheng, Maude, Brotherson, \& Merritts, 2016). 
However, little is known about the extent of the use of ABA-based interventions in mainland China. For example, there is no research about the proportion of ABA-based interventions used when compared to other interventions, that are utilized by autism organisations and families. Similarly, little is known about how ABA-based interventions are used by Chinese professionals and researchers and the effectiveness of these interventions. For example, it is not clear whether and how targeted behaviors have been changed after interventions; how and which family members are involved in the interventions; and whether the interventions also result in psychological changes in the family members. Answers to the above questions will depict the current status of the ABA-based interventions in mainland China.

Researching these questions will help deepen the understanding of ABA-based interventions that orginate from the West, in diverse cultural contexts. This can enrich the development of novel ABA-based interventions, clarify the optimal settings in which ABAbased interventions can be applied, and facilitate the dissemination of the science of behavior analysis internationally. All of these help shape how ABA-based interventions develop in the future. For example, eye contact is considered a pivotal and important behavior in training for children with autism to attend socially (Foxx, 1977; Helgeson, Fantuzzo, Smith, \& Barr, 1989). However, the interpretation of eye contact differs across cultures. In Eastern cultures, it is perceived very differently from Western norms (Akechi et al., 2013). Specifically, in East Asian cultures prolonged eye gazing at another person would be considered aggressive and/or disrespectful towards others (Uono \& Hietanen, 2015). Therefore, while intensive and long-term behavior analytic intervention programs (e.g., Perry, Koudys, Prichard, \& Ho, 2019) including strategies such as a progressive model of teaching (e.g., Cook et al., 2017; Rapp et al., 2018) and differential reinforcement (e.g., Hall, Maynes, \& Reiss, 2009; Jeffries, Crosland, \& Miltenberger, 2016) have been found to lead to optimal outcome for children in the West, these conclusions cannot be transferred across cultures without further analysis (Lovaas, 1987; Remington et al., 2007).

Chang and Zaroff (2018) have reviewed local service programs, supporting policies, and the use of ABA-based interventions in mainland China and Hong Kong. However, their review was limited to studies written in the English and did not include relevant findings published in Chinese. Given that quite a few Chinese researchers publish their work in Chinese journals, it is likely that Chang and Zaroff's review missed some important work and consequently, did not reveal the true extent of the use of ABA-based interventions in China. 
In addition, their review did not report the feature of intervention services, or mearsurement tools and the quality of the research method. To overcome this limitation, the present review includes literature published in both English and Chinese. The review reported here focussed on two main research questions:

1. What is the status of ABA-based interventions for autism in mainland China?

2. What empirical methods have been used to study ABA-based interventions in mainland China?

\section{Methods}

To review empirical studies regarding ABA-based intervention in mainland China, two systematic reviews were conducted using the methodology of the Preferred Reporting Items for Systematic Reviews and Meta-Analysis (PRISMA) (Moher et al., 2009; 2015).

\section{Search strategy}

The search covered databases of journals in English or Chinese. In the English language databases, the key words used were 'Autism Spectrum Disorder', 'Applied Behavior Analysis' and 'mainland China', and the variants of these terms (e.g., 'ABA', 'intensive behavior intervention', 'early intensive behavior intervention') according to the thesaurus based on the Pearl Harvesting method (Sandieson, 2006, 2019). Boolean operators such as AND and OR were used in combination in the command line, the truncation operator

'*' was used to capture all variations of similar terms, e.g. autism and autistic become autis*, and restriction of exact words was ensured by using double quotation marks around a term. For example, "applied behavior analysis" would return only those papers that refer to the exact UK spelling of behavior. However, the UK spelling "behavior" and the US spelling "behavior" were both searched.

In the Chinese language databases, the following key words were used: Autism ('自 闭症” or “孤独症”) and Applied Behavior Analysis (“应用行为分析”). The search strategy were the same as that in the English language review. The exact combinations of search terms used for the English and Chinese databases can be found in Appendix 1.

\section{Selection criteria}

To be included in analyses, all studies need to meet the following selection criteria: 
1) They included children with autism; they also could include parents (mothers, fathers), other caregivers (e.g., grandparents) of these children, or professionals who worked with these children (e.g., therapists);

2) They focused on applied behavior analytic interventions or interventions that were based on or referred to Baer, Wolf and Risley (1968; 1987);

3) They were conducted in mainland China with a local population;

4) They were published in peer-reviewed journals;

5) They reported empirical studies that were either experimental, such as singlesystem design studies (SSDs), or non-experimental studies, such as quantitative surveys, qualitative interviews, census data and descriptive data.

\section{English language databases}

Five English databases and sixteen additional English journals were searched. English databases, included ERIC (Educational Resources Information Center - ProQuest), Web of Science, ProQuest Social Science, SCOPUS and PubMed. The initial search took place between 10 -25 January 2017 and this was updated between 10-13 January 2018. Sixteen journals were hand searched, including Journal of Applied Behavior Analysis, Journal of Early and Intensive Behavior Intervention, Analysis of Verbal Behavior, Journal of the Experimental Analysis of Behavior, Behavior Analysis in Practice, European Journal of Behavior Analysis, Behavior Analyst, Behavioral Interventions, Behavior Analyst Today, Journal of Positive Behavior Interventions, and Behavior and Philosophy, Behavior Modification, Research in Autism Spectrum Disorder, Research in Developmental Disabilities, Research and Practice for Persons with Severe Disabilities, Journal of Autism and Developmental Disorder.

\section{PRISMA chart of English language databases}

Figure 1 presents the PRISMA chart that shows the results of the English language search. The search across databases, additional backwards search, and hand-search of journals produced 273 articles. These articles reduced down to 251 articles after duplicates removed. An additional search was conducted through a backward literature search, i.e., searching the bibliography of the final included articles, which produced an additional 8 papers. The total of 259 papers reduced to 27, after 232 articles were removed because they proved irrelevant in their titles and/or abstracts). The full text of these 27 articles were read 
for eligibility inclusion and 7 of them were selected for the final analyses. Figure 1 outlines the reasons for excluding the other 20 excluded articles.

[Figure 1 inserts here]

Figure 1: PRISMA chart of English articles

\section{Chinese language databases}

A separate systematic review was conducted using three Chinese language databases, including China National Knowledge Infrastructure (CNKI), WeiPu (VIP) and Wanfang, which are considered the most frequently used Chinese academic databases (e.g., Sun et al., 2013). Articles from CNKI were searched on 26-28 January 2017 and articles from VIP were search on 4-5 February 2017. An updated search including the three databases was conducted again between 11 -15 January, 2018. Since Chinese journals were all released in open access through databases (Huang, 2004; Wang \& Yao, 2005), no additional journals were searched.

\section{PRISMA chart of Chinese language databases}

Figure 2 is the PRISMA chart showing the procedure of the search and review for articles in the Chinese language. The search produced 889 records, which filtered down to 749 articles after duplicates were removed. An additional search was conducted through a backward literature search and produced 2 additional records. A total of 173 records filtered down to 28 records after removing 578 papers which had titles and/or abstracts that were irrelevant. The full texts of 28 articles were read for the final analyses. The reasons for the 145 excluded articles are presented in Figure 2.

[Figure 2 inserts here]

Figure 2: PRISMA chart of Chinese articles

\section{Excluded articles}

As shown in Table 1, a total number of 165 articles were excluded full-text screening procedures. There were 20 English articles and 145 Chinese articles passing the duplication screening and eligibility screening. Of the 20 English papers, around half of these articles $(n=8)$ were excluded due to not focusing on populations in mainland China (e.g., they focused on the populations in Hong Kong; e.g., Leung \& Wu, 1997; Ling \& Mak, 2012 ). For 
the 145 Chinese articles which did not pass the duplication screening and the eligibility screening, the majority of them were further excluded because they were non-empirical reviews on the theories and practices of ABA-based interventions conducted in the West, i.e., 72 of them were general review on autism or treatment approaches (e.g., You \& Yang, 2006 ) and 20 of them were $\mathrm{ABA}$ review such as outlining what ABA-based interventions are and how they can be implemented (e.g., Liu \& Li, 2007), offering an overview of Pivotal Response Training (PRT), a specific ABA-based intervention (e.g., Huang, Chen \& Li, 2010), and the usage of EIBI in the West (e.g., Wang \& Kang, 2011). In addition, 48 of the excluded Chinese articles were not solely about ABA but about eclectic methods, where researchers regarded $\mathrm{ABA}$ as a type of interventions and used with other approaches (e.g., Peng \& Yu, 2014).

\section{Interobserver agreement}

The first author YL undertook the majority of the search of both the English and the Chinese literature. In order to assess the internal validity of these reviews, a second reviewer independently searched and read the above databases and journal papers. Two authors discussed reasons for exclusion, such as 'empidemilogicial study', 'eclectic approach', 'not focused on mainland China' and 'other empirical study but not focused on ABA-based interventions' (see Table 1 for reasons of exclusion).

YL and the third author (WH) reached $100 \%$ of agreement in the English database and journal paper searches. YL and the fourth author (YX) reached $99.47 \%$ of agreement in Chinese database searches. Four disputed articles were discussed by YL, KD, and YX to a reached consensus and further clarifications were sought from the relevant authors before making the decisions to include or exclude from the review. In the end, all the four papers were clarified as not about ABA-based interventions.

\section{Quality assessment of single-case design}

Single-case research design (SCD) is commonly used in developing and evaluating behavior analytical interventions, including those in the field of special educational needs (Kratochwill et al., 2013), and interventions to support individuals with intellectual disabilities and/or autism (Matson, Turygin, Beighley, \& Matson, 2012). The methodological rigor of single case design were assessed by What Works Clearinghouse (WWC) standards (Institute of Education Sciences, 2017). The WWC reviewers categorised studies into three 
types, i.e., meeting evidence standards, meeting evidence standards with reservations, and not meeting evidence standards. In oder to meet evidence standards: a) The independent variable (i.e., the intervention) must be systematically manipulated and the study must identify when and how the independent variable conditions changed; b) An inter-assessor agreement (IOA) must be collected by more than one assessor in each phase and at least $20 \%$ of the data points in each condition (e.g., baseline, intervention); and c) The study must have the minimum number of phases and data points per phase to demonstrate the intervention effects. The quality of group design and non-experimental design articles were not assessed, because single-system designs (Hitchcock, Kratochwill, \& Chezan, 2015; Institute of Education Sciences, IES, 2017; Kratochwill et al., 2013) are the main research designs in the clinical and research area of behavior analysis. In addition, the limited number of Randomised Controlled Trials (RCTs) made the quality of assessment not significant. The first author (YL) and the fifth author (HC) reached 100\% agreement on the quality assessment of the single case design studies.

\section{Results}

The two systematic reviews generated 35 relevant articles, including both English and Chinese articles. Among these artices, there were 24 experimental research design studies and 11 non-experiments, such as qualitative and quantitative research design articles. The details of the articles can be found in Table 2 .

\section{Research trend related to $A B A$ and autism}

A total of 200 articles were extracted for analyses at the full-text eligibility level (Table 1), i.e., 173 Chinese articles (145 excluded articles and 28 included articles) and 27 English articles (20 excluded articles and 7 included articles). In order to understand the research trend on children with autism and ABA-based interventions related contexts in mainland China, a further analysis was carried out on 103 articles, which included 35 final articles and excluded 68 articles with distinct reasons of 'ABA review' (Table 1, second row, third column) and 'eclectic approach' (Table 1, second row, fourth column).

[Figure 3 inserts here]

Figure 3: Research trend related to ABA and autism 
In Figure 3, the horizontal line represents an equal number of 3-year divide. As the search ended on January 2018, the year of 2018 was grouped into the '2015-2018' category. The vertical line represents number of articles published in peer-reviewed journals. As indicated in Figure 3, articles coded as 'ABA review', eclectic approach' and 'ABA empirical studies' increased yearly. Empirical research increased after 2005. Before that, most of the literature focussed merely on introducing and reviewing ABA related research from the West. However, in the short time span since 2005, there has been a relatively broad coverage of behavior analytic topics (see No.6 of the results section). In addition, eclectic approach articles increased from 2009 onwards and empirical studies about ABA increased largely from 2012 onwards.

\section{Empirical methods}

Among the 35 articles, 14 articles used experimental study of single/multiple-case design, 10 articles used experimental study of group design and 11 articles were nonexperimental empirical studies such as qualitative interviews (See Table 2 for details).

Of the 14 single/multiple case design studies, 9 studies used single-case design. To be specific, 5 of them used A-B-A design studies (Huo, Liu, \& Hu, 2016; Qian, 2016; Wang, 2016; Xiao \& Yu, 2015; Zhen \& Li, 2017); 3 studies used A-B-A-B reversal design studies (Shen, 2017; Yang, Zhu, \& Cao, 2012; Hu, Chen, \& Zheng, 2016), and one used A-B research design study (Sun \& Wei, 2011).

Of the remaining 5 single-case studies, Xu, Wang, Lee and Luke (2017) used changing criterion design and 4 studies used multiple-baseline design, with $\mathrm{Hu}$ and Fan (2014) using an A-B multiple baseline design; Hu, Xu, Xu and Feng (2015) using an A-B-A multiple baseline design across subjects; Hu, Liu, Fan, \& Zhen (2016) using multiple baseline design across subjects. Lee, Feng, Xu and Jin (2017) used multiple baseline design across behaviors.

Of the 10 articles that used group research design, five used a within-group design, i.e., making measurement before and after intervention for the same group of participants (Duan \& Niu, 2013; Liu \& Chen, 2012; Ma, Cui \& Zhang, 2016; Shi, Yu, Guo, \& Li, 2007; Xiong et al., 2010). Five studies used a within-group design and between-group research design, i.e., comparing the experimental group and the control group, plus pre- and post-test on each group (Ding et al., 2015; Wang, 2008;Xu, Yao \& Yang, 2017; Xu et al., 2018; Zou et 
al., 2008); 3 of these 5 studies used Randomized Control Trials (RCT) related to ABA-based interventions on the Chinese population (Wang, 2008; Xu, Yao \& Yang, 2017; Xu et al., 2018).

Of the 11 non-experiment empirical studies, 7 studies were empirical case studies without quantitative data (Han, 2016; He, 2017; Ma, 2017; Shao, Xu \& Zhang, 2014; Wang, 2016; Zhong, 2016; Zhu, 2013). These studies used descriptive words to indicate the child's behavior changes after ABA-based intervention. For example, Han (2016) reported the implementation of functional behavior analysis reduced a boy's disruptive behavior in the classroom. Four of these studies lacked quantitative data (Han, 2016; He, 2017; Shao, Xu, \& Zhang, 2014; Wang, 2016); one article lacked intervention and maintainance stage data (Ma, 2017) and 2 case study articles were reported as empirical studies by authors but lacked a clear research design (Zhong, 2016; Zhu, 2013). Two of the non-experiment emprical studies were qualitative interviews. Specifically, Guo, Liu and Du (2006) used telephone interviews with 64 parents to assess the type of school their children were enrolled in and their academic record at school; Liao, Dillenburger and Buchanan (2018) interviewed parents and professionals in England and China to explore cultural factors influencing ABA service delivery. The remaining 2 non-experiment studies collected children's past documentary data (archived data, Nichols, 2001) and parents' training data for research purpose. Specifically, Zhou et al. (2014) analysed the registration data between 1993 to 2012 at 'Stars and Rain', one of the earliest autism NGO founded by a Chinese mother, and surveyed 100 members of centres of Heart Alliance Autism Network, the organization started by Stars and Rain in 2005 to promote quality services and sharing resources (Zhou et al., 2014). Guo (2006) analyzed parents' training data to describe the characteristics of parental training and challenges faced by Chinese parents.

\section{Quality of the single case design studies}

All of the 14 single case design studies focused on improving children's behavior using ABA-based interventions. The methodological rigor of the 14 single/multiple case design were assessed using What Works Clearinghouse (WWC) standards (Institute of Education Sciences, 2017). Results showed that all 14 articles met the first level of quality; 8 of the articles met the criterion on inter-assessor agreement (IOA). For articles in which IOA process was not reported at all or was not detailed enough, emails were sent to corresponding authors for clarifications. If no responses were received after three weeks, the papers were excluded and deemed as not having met IOA level; 4 articles had the required number of 
phases and data points per phase without reservation, and 2 articles met WWC pilot singlecase design standards with reservations (Table 3).

\section{Measurement tools}

The most commonly used assessment and diagnostic tools in mainland China were Childhood Autism Rating Scale (CARS) (Schopler et al., 1986) and the Autism Behavior Checklist (ABC) (Krug, Arick, \& Almond, 1980). Of the 24 experimental studies, 10 articles did not menthioned diagnostic criteria (Duan \& Niu, 2013; He, 2017; Huo, Liu \& Hu, 2016; Hu, Xu, Xu , \& Feng, 2015; Hu \& Fan; Ma, 2016; Shen, 2017; Wang, 2008; Yang, Zhu \& Cao, 2012; Zheng \& Li, 2017; Sun \& Wei, 2011); 5 articles indicated the diagnoses of participants were confirmed by authorative hospitals (Hu, Chen, \& Zhen, 2016; Hu, Liu, Fan, \& Zhen, 2016; Wang, 2016; Xiao \& Yu; 2015). CARS was used in 6 papers (Shi, Yu, Guo, \& Li, 2007; Wang, 2008; Wang, 2016; Xu, Yao \& Yang, 2017; Xu et al., 2018; Zou et al., 2008). ABC was used in 3 papers (Duan \& Niu, 2013; Xiong et al., 2010; Shen, 2017).

In addition, functional developmental tools, such as the Chinese version Psychoeducational Profile-Third Edition (PEP-3) (Heep Hong Society, 2009; Schopler, Lansing, Reichler, \& Marcus, 2005) were used by Chinese researchers in 3 studies (Hu \& Fan, 2014; Ma, 2017; Wang, 2008; Xu et al. 2018). The Gesell Developmental Scale (Gesell, 1925) was used by Shi, Yu, Guo and Li (2007). The Wechsler Primary and Preschool Scale of Intelligence-Revised (WPPSI-R) (Wechsler, 1989) was used by $\mathrm{Hu}$ and Fan (2014), Hu, Liu, Fan and Zhen (2016), and Qian (2016). All of the 14 single-case design studies used direct behavior observations to collect data at baselines and/or different phases of the intervention (Hitchcock, Kratochwill, \& Chezan, 2015).

\section{Target behaviors}

The behaviors targeted with ABA-based interventions in mainland China were varied. The majority of papers focused on the overall performance improvements (Ding, Zhong, Cheng, \& Jiang, 2015; Xiong et al., 2010; Zou et al., 2008), while some emphasized social communication (Hu \& Fan, 2014; Qian, 2016; Shao, Xu, \& Zhang, 2014; Zheng \& Li, 2017; Hu, Liu, Fan, \& Zhen, 2016; Hu, Chen, \& Zhen, 2016), language (Ma, Cui, \& Zhang, 2016), aggressive behavior (Hu \& Fan, 2014; Zhong, 2016), theory of mind (Hu, Xu, Xu, \& Feng, 2015), interference behavior (Wang, 2016), self-injurious behavior (Xiao \& Yu, 2015), seatleaving behavior (Yang, Zhu, \& Cao, 2012) and food selecting behavior (Zhu, 2013).

\section{ABA-based interventions}


A variety of $\mathrm{ABA}$-based interventions were used in China, including Picture Exchange Communication System (PECS; Hu \& Fan, 2014; Qian, 2016; Shao, Xu, \& Zhang, 2014; Zheng \& Li, 2017), Speech-generating devices (Hu, Liu, Fan, \& Zhen, 2016); Structured social play (Hu, Chen, \& Zhen, 2016); Discrete Trial Teaching (DTT; Zheng \& Li, 2017; Zou et al., 2008), Pivotal Response Training (PRT; Wang, 2016) and functional assessment (Wang, 2016; Xiao \& Yu, 2015; Yang, Zhu, \& Cao, 2012). In addition, Zhou et al. (2014) reported that of the 100 autism Non-Governmental Organizations (NGOs) of the Heart Alliance, 99 organisations provided ABA-based interventions, 73 provided sensory integrations intervention and 36 provided Treatment and Education of Autistic and related Communication Handicapped Children (TEACCH). A total of 87 organisations provided more than two approaches (Zhou et al., 2014).

The duration of program was short, e.g., around three months (Ding, Zhong, Cheng, \& Jiang, 2015; Guo, 2006; Xiong et al., 2010). Most autism organisations served for young children, and only 18 out of 100 centres provided services for adults, aged 18 years or older. The number of professionals working at each organisation ranged widely from 3 to 75 , with a median staff to child ratio of 1: 2.77 (Zhou et al., 2014).

Some researchers explored cultural differences that affected the service delivery of ABA-based interventions across countries (Liao et al., 2018) and culturally adapted services in China (Xu et al, 2018).

\section{Parental involvements and mental health}

Parents took an active role in ABA-based intervention programs in mainland China (Guo, 2006; Wang, 2008; Xiong et al., 2010; Zhou et al., 2014). Results showed 4 out of the 10 group design articles studied parental involvements in children's ABA-based intervention programs, such as the exploration of low intensity of behavior analytic training when parents involved in children's ABA-based intervention programs (e.g., Xu, Yao \& Yang, 2017; Xu et al., 2018), and child's behavior change after parents had ABA training (e.g., Wang, 2008; Zou, 2008). Many parents, who travelled from their home to one of the major cities to access quality parent training, chose to leave their job (Liao et al., 2018). Of 100 autism NGOs included in Zhou et al. (2014), 73 organisations provided both children and parent training, 24 organisations solely provided children intervention, and 3 organisations solely provided parent training. The effectiveness of parent training was demonstrated also by Wang (2008), who reported improvements in interaction between the parent and the child with autism after 
parent-focused training. Parents were more accepting of their child, clearer about their child's interests, more able to deal appropriately with the child's challenging behavior, and able to better interact and communicate with their child.

With regards to parental mental health, the Chinese model of including parent training provided parents a forum to share their feelings, to support each other, and to some extent, to relieve psychological pressure. Xiong et al. (2010) conducted a study comprised 76 mothers and children with autism. In their 70 Days' Project, mothers were trained to support their own children under the supervision of ABA professionals. The study revealed that mothers' depression and anxiety level did not change, however, they suggested that further strengthening of training for parents could help relieve of mothers' mental health issues.

\section{Child outcomes}

With regards to child outcomes, the majority of the Chinese researchers reported optimal outcomes in favour of ABA-based interventions. Zhou et al. (2014) reported that, over a twenty-year period (1993 to 2012), ABA-based interventions were highly effective for students at Heart Alliance and Stars and Rains. Wang (2008) conducted an assessment of 76 mothers after three months intervention of a parent-focused ABA training program, where interventions were based on the parent-child dyad under a teacher's supervision. Results showed notable improvement in the children's abilities with regards to sensory regulation, social skills, physical motor skills, verbal behavior and speech, and self-care skills. Interestingly, girls showed a greater improvement than boys in terms of social ability and independent skills; older children had better outcomes than younger ones in terms of self-care competence.

A number of researchers reported specifically positive effects of ABA-based interventions on language and communication skills and challenging behaviors. For example, Liu and Chen (2012) conducted ABA communication training with 41 children with autism aged 21/2 - 5-years-old and found that the children's pronunciation, single word sentences, and expression significantly improved after training. Hu and Fan (2014) reported children's ability with regards to 'theory of mind' improved significantly and Zhong (2016) revealed that after 3 months ABA-based training, the participant's aggressive behavior reduced significantly. 
Ding, Zhong, Cheng, and Jiang (2015) assessed the physical ability, emotional ability, social ability and school behavior of 66 significantly challenged children with autism after they had received 3 months training in ABA program using the Pediatric Quality of Life Inventory Measurement Models (PedsQLTM). While results showed improved quality of life (physical functioning), however, due to some program inflexibility, fewer improvements were achieved in terms of emotional and social communication. Xiong et al. (2010) trained 76 mothers and children with autism and found that children's social skills, language, motor ability and self-care ability increased significantly.

\section{Financing of services}

Funding for autism in China is limited to services within each local province (Liao et al., 2018), consequently, most of the parents who wanted to avail of ABA-based services had to finance the interventions themselves. This meant that these families carried a larger financial burden $(¥ 19582.4$ per year $=\$ 2,846.94$, currency on 20 August 2018) than families of children with physical disability (¥16410.1 per year $=\$ 2,385.74)$ or intellectual disability ( $¥ 6391.0$ per year $=\$ 929.13$ ) (Xiong et al., 2011). This additional cost was incurred in the context of low wages, i.e., according to the recent report by National Bureau of Statistics (2018), in non-rural regions, the average annual disposable income was $¥ 36,396$ per annum $(=\$ 5,291.27)$ and in rural regions, the average annual disposable income was $¥ 13,432$ per annum $(=\$ 1,952.75)$.

\section{Discussions}

Two systematic reviews were conducted regarding ABA-based interventions in mainland China, one searching for English language papers and the other searching for literature in Chinese language. The current reviews identified 35 empirical studies specifically focusing on ABA-based interventions for children with autism in mainland China. However, this relatively low number of publsihed studies does not mean ABA-based interventions have not been used widely in mainland China. In fact, ABA-based interventions were originally introduced by autism NGOs since 2000s (Zhou et al., 2014), and most Chinese indigenous research was driven by the needs of families rather than professionals and researchers. In addition, a local autism NGO, Shenzhen Autism Society (SAS, 2013) reported that $88.89 \%$ of 56 autism organisations across the nation used ABA-based interventions in 2012. 
One possible reason for the lack of published empirical research in mainland China is that the ABA-based interventions have been used mainly by therapists and parents at autism organisations rather than researchers at professional institutions. The former typically applied interventinos at clinic settings focussed on customers' needs rather than on publishing their work in peer-reviewed journals. The present review identfied that some studies mixed the use of ABA-based interventions with other approaches, such as sensory integration, music therapy and language therapy. However, evne when these studies were included the number of empirical studies was still less than 100 articles. This is likely due to the fact, that most therapists have few opportunities to receive good quality research training in ABA and this constraints their research abilities in the field.

Another reason may be that, there are few qualified ABA professionals in mainland China, which may result in the reduced quantity of published research articles. Behavior Analyst Certification Board (BACB) provides professional credentialing in the field of behavior analysis internationally. Board Certified Behavior Analysts (BCBAs) and Board Certified Behavior Analysts - Doctoral Level (BCBA-Ds) are graduate-level certificates that have demonstrated competency not only in directing and conducting applied behavior analytic interventions, but also in designing and implementing behavior analytic research (Shook \& Neisworth, 2005). However, there are only 22 Board Certified Behavior Analysts (BCBAs), 2 Board Certified Behavior Analysts - Doctoral Level (BCBA-Ds) and 85 Board Certified assistant Behavior Analysts (BCaBAs) in mainland China (BACB, 2019), whereas there are 32,008 BCBAs and 3,437 BCaBAs around the world (BACB, 2019). The first Behavior Analyst Certification Board (BACB, 2019) verified course sequence was established at a Chinese university in 2017.

Results reported here show that the majority of the Chinese researchers believed children's ability improved with ABA-based interventions. Yet, few researchers reported to what extent $\mathrm{ABA}$-based interventions worked and how external and environmental variables influenced their effectiveness. This raises concerns about the validity and reliability of research outcomes. In addition, utilisation of most commonly used instruments by Western researchers (e.g., Eikeseth, Smith, Jahr \& Eldevik, 2007; Peters-Scheffer, Didden, Korzilius, \& Sturmey, 2010), such as the Vineland Adaptive Behavior Scale (Sparrow, Ciccetti, \& Saulnier, 2016), and the Wechsler Intelligence Scale for Children (Wechsler, 1991) to assess effectiveness of the interventions was rather limited in the Chinese papers reviewed here. 
These results indicate that ABA-based interventions in mainland China are more about the practical application rather than theoretical exploration and research outputs. In addition, this review reflected a relatively short time of indigenous research on ABA-based interventions in mainland China. Very few studies have explored cultural adapted service delivery (e.g., Xu et al, 2018; Zhou et al., 2018), the efficiency of skill acquisition (e.g., Cariveau, La Cruz Montilla, Gonzalez, \& Ball, 2019) and treating problematic behaviors based on experimental verification of different functions of behavior (e.g., Gover, Fahmie, \& McKeown, 2019).

Interestingly, one of the main features that became apparent in this review was the importance placed on parental involvement. Findings reported here are consistent with the Shenzhen Autism Society (SAS, 2013) who reported that over half (56\%) the founders of organisations that deliver autism interventions were parents of children diagnosed with autism, who wanted to help their own child and others like them. The reason for this intense focus on family is the Chinese culture and policy system. Children's educational development is regarded as one of core characteristics of a successful family in Chinese culture (Huang \& Gove, 2012), where parents of children with disability, including children with autism, spent more time and energy on parenting and education that parents of other children (Liao et al., 2018). In addition, the lack of financial support from the authorities and lack of availability of quality professionals focusses caring issues on the family (Wang et al., 2013). Parents, especially those who come from rural areas, either have to take an active role to work as a therapist or move out-of-place of residence to access quality services. Finally, parental training provided participants a platform to share their feelings and improve mental health (Liao et al., 2018, McCabe, 2003, 2013). However, the possible problem of parental involvement is that parents, especially mothers, have to give up jobs to help their children avail of quality treatment services. Parents' quality of life might be influenced (Liao, 2017) and there is a potential for emotional conflict between being a mother and a professional, especially in dealing with problematic behaviors (McCabe, 2007).

Importantly, a lack of systematic understanding of $\mathrm{ABA}$ was reflected in many of the studies in this review. For instance, some papers mixed ABA up with other intervention approaches or attributed the effectiveness of ABA-based approaches to something else (Wang, 2016; Xiao \& Yu, 2015). Some authors misread the origins of ABA. For example, some researchers stated that it was Lovaas who developed ABA as an intervention for children with autism in the 1970-80s (e.g., Xiong et al. 2010, p.971). This is a widely held 
misunderstanding of the history of ABA and autism, even in the West. In fact, ABA is not a 'therapy for autism' (Dillenburger \& Keenan, 2009) and it was Ferster and colleagues (Ferster \& DeMyer, 1961) and Oppenheim (1974) who first explored ABA-based interventions to support children with autism. In addition, single system experimental design studies dominate the field, however, some of the Chinese research still lacked the expected rigour with regards to experimental control, generalisation, or maintenance data (Johnston \& Pennypacker, 2010).

Finally, of the most papers included in this review, the term 'ABA' was used rather loosely. For example, specific ABA-based interventions (mainly Discrete Trial Teaching; DTT) were used along with other behavioral (e.g., Treatment and Education of Autistic and related Communication handicapped Children; TEACCH), or non-behavioral approaches, such as sensory integration, auditory integration (Wang et al., 2011), music therapy (Zhang, 2005), and pharmacological treatments. However, usually, researchers did not differentiate to which intervention approach the effectiveness of the overall intervention was attributable (McCabe, 2013), and there was little information on how control groups were managed (Clark \& Zhou, 2005). This indicates that some of the Chinese researchers or parents regarded $\mathrm{ABA}$ as one type of method rather than a science that encompasses a large range of strategies, disciplines and techniques (Cooper, Heron, \& Heward, 2007). It is doubtful that most of the 'ABA' interventions used in mainland China are truly behavior analytic in nature (Baer, Wolf, \& Risley, 1968), because for the most part, 'ABA' was used synonymously with DTT (Liao, 2017).

\section{Strengths, limitations and recommendations}

To our best knowledge, this is the first systematic literature review that included both English and Chinese papers. The present systematic review reflects the status of ABA-based interventions in mainland China and thus provides practitioners, researchers and policymakers with a landscape of behavior analytic interventions on children with autism in China.

On the other hand, clearly the review has a number of limitations. While the search focused on published articles regarding autism and ABA in mainland China, grey literature was not searched, thus unpublished research studies such as doctoral or masters level were not included. In addition, the search was conducted before Jan 2018. It is possible that some peer-reviewed articles have been published since then and future researchers are encouraged to replicate this review periodically. 
This paper sheds lights on the pressing needs of empirical research and systematic training on behavior analytic interventions on mainland China. These can be achieved in three ways: First, it is recommended that more Chinese universities open behaviour analytic intervention courses, such as the verified course sequence by Behavior Analyst Certfication Board (BACB), providing training to students at undergraduate and postgraduate levels. Second, since culturally adapted research is lacking in many areas of science, it is important to explore and compare the application of ABA-based interventions in different cultural contexts. Special education professionals are encouraged to receive systematic research training and to publish data-driven articles of their clinical practice. This may lead not only to a better understanding of behavior change procedures that support clients with autism, but also contribute to the exploration intervention strategies across cultures. Third, books and research instruments require adaptation and validation into the Chinese indigenous cultures. It is imperative to validate more Chinese assessment tools in research and clinical services. For example, the widely used Vineland Adaptive Behavior Scale (Sparrow, Ciccetti, \& Saulnier, 2016) is only available in traditional Chinese characters and validated in Taiwan in 1990 (Zhang, Guo, \& Wang, 2017). There are very few trainers on mainland China for the Autism Diagnostic Observation Schedule (ADOS), one of the mostly commonly used diagnostic tool in Western hospitals. Therefore, service providers should consider distance training courses or workshops, and invite experts from abroad where no local trainers are available. Last but not the least, parents working as therapist can relieve the shortage of special needs professionals. The awareness of parent training is increasing in mainland China and, given the large geographical area of mainland China, it could be beneficial if tele-health practices were used facilitate parents' hands-on exeprience (e.g., Dai et al., 2018).

\section{Conclusions}

The present study revealed a lack of fundamental knowledge in the science of behavior analysis in mainland China. The review suggests a deficit in theoretical and practical knowledge of ABA by Chinese researchers that was rather concerning. It is imperative for future Chinese researchers to conduct and publish experimental and nonexperimental research in a more rigorous and well-designed manner (Pang et al., 2018). In particular, studies on the status of ABA-based interventions and service delivery are encouranged to adopt evidence-based methods by local Chinese policy makers. As these studies become more widespread, they should include evidence for treatment fidelity and 
social validity, which would help dispel misinformation surrounding eclectic approaches and guide policy development. Chinese researchers are encouraged not only to replicate the Western model, but also to work on indigenous models that are adapted to the local educational system without distortion of the basic science of behavior analysis.

\section{References}

Akechi, H., Senju, A., Uibo, H., Kikuchi, Y., Hasegawa, T., \& Hietanen, J. K. (2013). Attention to eye contact in the West and East: Autonomic responses and evaluative ratings. PLOS ONE, 8(3), e59312. doi:10.1371/journal.pone.0059312

American Psychiatric Association (APA). (1994). Diagnostic and statistical manual of mental disorders (4th ed.). Washington, DC: Author.

American Psychiatric Association (APA). (2013). Diagnostic and statistical manual of mental disorders (5th ed.). Arlington, VA: Author.

Baer, D. M. (1962). Laboratory control of thumbsucking by withdrawal and re-presentation of reinforcement. Journal of the Experimental Analysis of Behavior, 5(4), 525-528. doi:10.1901/jeab.1962.5-525

Baer, D. M., Wolf, M. M., \& Risley, T. R. (1968). Some current dimensions of applied behavior analysis. Journal of Applied Behavior Analysis, 1(1), 91-97. doi:10.1901/jaba.1968.1-91

Baer, D. M., Wolf, M. M., \& Risley, T. R. (1987). Some still-current dimensions of applied behavior analysis. Journal of Applied Behavior Analysis, 20(4), 313-327. doi:10.1901/jaba.1987.20-313

Bluma, M. S. (2001). Portage guide to early education (Applied to children aged 0-6 years old) (S. Miao, Trans.). Beijing: People's Education Press.

Cariveau, T., La Cruz Montilla, A., Gonzalez, E., \& Ball, S. (2019). A review of error correction procedures during instruction for children with developmental disabilities. Journal of Applied Behavior Analysis, O(0). doi:10.1002/jaba.524

Chang, K., \& Zaroff, C. M. (2018). Applied behavior analysis in autism spectrum disorders in China and Hong Kong. ACTA PSYCHOPATHOLOGICA, 3(5), 1-5.

Chen, Y. F. (2002). Chinese classification of mental disorders (CCMD-3): Towards integration in international classification. Psychopathology, 35, 171-175.

China Disabled Persons Federation. (2009). Development assessment form for children with autism. Retrieved from http://www.cdpf.org.cn/zcwj/zxwj/200909/t20090923_38828.shtml

Clark, E., \& Zhou, Z. (2005). Autism in China: From acupuncture to applied behavior analysis. Psychology in the Schools, 42(3), 285-295. doi:10.1002/pits.20079

Cook, J. L., Rapp, J. T., Mann, K. R., McHugh, C., Burji, C., \& Nuta, R. (2017). A practitioner model for increasing eye contact in children with autism. Behavior Modification, 41(3), 382-404. doi:10.1177/0145445516689323

Cooper, J., Heron, T., \& Heward, W. (2007). Applied behavior analysis (2 ed.). Upper Saddle River, NJ: Pearson Prentice Hall. 
Dai, Y. G., Brennan, L., Como, A., Hughes-Lika, J., Dumont-Mathieu, T., Carcani-Rathwell, I., . . Fein, D. A. (2018). A video parent-training program for families of children with autism spectrum disorder in Albania. Research in Autism Spectrum Disorders, 56, 36-49. doi:https://doi.org/10.1016/j.rasd.2018.08.008

Dillenburger, K., Jordan, J. A., McKerr, L., \& Keenan, M. (2015). The Millennium child with autism: Early childhood trajectories for health, education and economic wellbeing. Developmental Neurorehabilitation, 18(1), 37-46. doi:10.3109/17518423.2014.964378

Dillenburger, K., \& Keenan, M. (2009). None of the As in ABA stand for autism: Dispelling the myths. Journal of Intellectual \& Developmental Disability, 34(2), 193-195. doi:10.1080/13668250902845244

Ding, D., Zhong, W., Cheng, X., \& Jiang, S. (2015). Effectiveness of applied behavior analysis training on the quality of life in children with autism. [应用行为分析训练对 孤独症儿童生存质量的影响]. Chinese Journal of Clinical Psychology, 23(3), 564566. doi:10.16128/j.cnki.1005-3611.2015.03.041

Duan, Q., \& Niu, X. (2013). Efficacy observation of behaivour intervention on childen with autism. [儿童孤独症行为干预的效果观察]. China Journal of Pharmaceutical Economics, 8, 82-83.

Durand, V. M., \& Crimmins, D. B. (1988). Identifying the variables maintaining selfinjurious behavior. Journal of Autism and Developmental Disorders, 18, 99-117.

Eikeseth, S., Hayward, D., Gale, C., Gitlesen, J.-P., \& Eldevik, S. (2009). Intensity of supervision and outcome for preschool aged children receiving early and intensive behavioral interventions: A preliminary study. Research in Autism Spectrum Disorders, 3(1), 67-73.

Eikeseth, S., Smith, T., Jahr, E., \& Eldevik, S. (2007). Outcome for children with autism who began intensive behavioral treatment between ages 4 and 7: A comparison controlled study. Behavior Modification, 31(3), 264-278. doi:10.1177/0145445506291396

Fein, D., Barton, M., Eigsti, I.-M., Kelley, E., Naigles, L., Schultz, R. T., . . . Tyson, K. (2013). Optimal outcome in individuals with a history of autism. Journal of Child Psychology and Psychiatry, 54(2), 195-205. doi:10.1111/jcpp.12037

Ferster, C. B., \& Demyer, M. K. (1961). The development of performances in autistic children in an automatically controlled environment. Journal of Chronic Diseases, 13(4), 312-345.

Foxx, R. M. (1977). Attention training: The use of overcorrection avoidance to increase the eye contact of autistic and retarded children. Journal of Applied Behavior Analysis, 10(3), 489-499. doi:doi:10.1901/jaba.1977.10-489

Frith, U. (1991). Autism and Asperger syndrome. Cambridge: Cambridge University Press.

Gesell, A. (1925). Monthly Increments of Development in Infancy. The Pedagogical Seminary and Journal of Genetic Psychology, 32(2), 203-208. doi:10.1080/08856559.1925.10534063

Gover, H. C., Fahmie, T. A., \& McKeown, C. A. (2019). A review of environmental enrichment as treatment for problem behavior maintained by automatic reinforcement. Journal of Applied Behavior Analysis, 52(1), 299-314. doi:doi:10.1002/jaba.508 
Guo, H., Liu, S., \& Du, Y. (2006). Follow-up visits on ABA-based training of children with autism. [孤独症儿童 ABA 训练随访]. Chinese Journal of Child Health Care, 14(5), 517-518.

Guo, R. (2004). Epidemiological investigation analysis of 5000 children between 0-6 years old with childhood autism in Tianjin City. Chinese Journal of Clinical Rehabilitation, $8(6), 1122-1123$.

Guo, Y. (2006). Training parents and professionals to help children with autism in China: The contribution of behavior analysis. International Journal of Psychology, 41(6), 523-526. doi:10.1080/00207590500492575

Hall, S. S., Maynes, N. P., \& Reiss, A. L. (2009). Using percentile schedules to increase eye contact in children with Fragile X syndrome. Journal of Applied Behavior Analysis, 42(1), 171-176. doi:10.1901/jaba.2009.42-171

Han, S. (2016). Case study on a functional analysis on the distruptive behavior of children with autism. [自闭症儿童课堂干扰行为功能评估的个案分析]. Scientific Consult, 19(5), 26-26.

He, X. (2017). A case study on the application of ABA on the emotional behavior of a child with autism. [ABA 应用于自闭症儿童情绪行为治疗的案例分析]. China Juveniles, 10(4), 296-296.

Heep Hong Society. (2009). Psychoeducational Profile - 3rd edition: TEACCH individualized psychoeducational assessment for children with autism spectrum disorders. [自闭症儿童心理学习教育评估-第三版]. Retrieved from https://www2.heephong.org/webprod/chs/publication/assessment tools and training packages/261

Helgeson, D. C., Fantuzzo, J. W., Smith, C., \& Barr, D. (1989). Eye-contact skill training for adolescents with developmental disabilities and severe behavior problems. Education and Training in Mental Retardation, 24(1), 56-62.

Hitchcock, J. H., Kratochwill, T. R., \& Chezan, L. C. (2015). What Works Clearinghouse standards and generalization of single-case design evidence. Journal of Behavioral Education, 24(4), 459-469. doi:10.1007/s10864-015-9224-1

Howard, J. S., Stanislaw, H., Green, G., Sparkman, C. R., \& Cohen, H. G. (2014). Comparison of behavior analytic and eclectic early interventions for young children with autism after three years. Research in Developmental Disabilities, 35(12), 33263344. doi:10.1016/j.ridd.2014.08.021

Hu, M., Xu, S., Xu, J., \& Feng, H. (2015). A case study on teaching the ability of theory of mind for children with autism based on applied behavior analysis. [应用行为分析法 对自闭症儿童心理理论能力教学成效的个案研究]. Journal of Modern Special Education (Higher Education), 14(7), 44-51.

Hu, X., Chen, T., \& Zheng, Q. (2016). A case study of an intervention on joint attention of preschool child with autism using structured play. [结构化游戏干预学前孤独症儿童 共同注意的个案研究]. Journal of Modern Education (Higher Education), 9, 49-55.

Hu, X., \& Fan, W. (2014). A case study: Improving autistic children's mand behavior and reducing their aggressive behavior by using the picture exchange communication 
system. [运用图片交换沟通系统改善自闭症儿童需求表达及攻击行为的个案研 究]. Chinese Journal of Special Education, 10(172), 40-45.

Hu, X., Liu, Y., Fan, W., \& Zheng, Q. (2016). Study on shaping the communication behaviors of three children with autism by using speech-generating devices. [运用语 音输出应用软件塑造孤独症儿童沟通行为的研究]. Journal of Modern Education (Higher Education), 7, 48-56.

Huang, C. (2004). A comparative study on the citation search function of three online Chinese periodical databases. [网上三大中文期刊数据库引文功能之比较]. Journal of Academic Libraries, 2, 49-52.

Huang, G. H., \& Gove, M. (2012). Confucianism and Chinese families: Values and practices in education. International Journal of Humanities and Social Science, 2(3), 10-14.

Huang, W., Chen, X., \& Li, D. (2010). Pivotal response treatment: A new trend in the education of autistic children by applied behavior analysis. [关键性技能训练法: ABA 应用于自闭症儿童教育干预的新方向]. Chinese Journal of Special Education, 10(124), 63-68.

Huo, W., Liu, Y., \& Hu, X. (2016). An intervention study of the facial expression recognition of children with ASD. [自闭症儿童面部表情识别的干预研究]. Chinese Journal of Special Education, 7(193), 52-58.

Institute of Education Sciences (IES). (2017). What Works Clearinghouse Procedures and Standards Handbook, Version 4.0. Retrieved from https://ies.ed.gov/ncee/wwc/Handbooks

Jeffries, T., Crosland, K., \& Miltenberger, R. (2016). Evaluating a tablet application and differential reinforcement to increase eye contact in children with autism. Journal of Applied Behavior Analysis, 49(1), 182-187. doi:10.1002/jaba.262

Jin, Z., Yang, Y., Liu, S., Huang, H., \& Jin, X. (2018). Prevalence of DSM-5 Autism Spectrum Disorder Among School-Based Children Aged 3-12 Years in Shanghai, China. Journal of Autism and Developmental Disorders, 48(7), 2434-2443. doi:10.1007/s10803-018-3507-z

Johnston, J. M., \& Pennypacker, H. S. (2010). Strategies and tactics of behavioral research. New York: Routledge.

Kanner, L. (1943). Autistic disturbances of affective contact. Nervous Child, 2, 217-250.

Kratochwill, T. R., Hitchcock, J. H., Horner, R. H., Levin, J. R., Odom, S. L., Rindskopf, D. M., \& Shadish, W. R. (2013). Single-case intervention research design standards. Remedial and Special Education, 34(1), 26-38. doi:10.1177/0741932512452794

Krug, D. A., Arick, J., \& Almond, P. (1980). Behavior checklist for identifying severely handicapped individuals with high levels of autisitic behavior. Journal of Child Psychology and Psychiatry, 21(3), 221-229. doi:doi:10.1111/j.14697610.1980.tb01797.x

Leung, J.-P., \& Wu, K.-I. (1997). Teaching receptive naming of Chinese characters to children with autism by incorporating echolalia. Journal of Applied Behavior Analysis, 30(1), 59-68. doi:10.1901/jaba.1997.30-59 
Liao, Y. (2017). Early applied behavior analytic interventions for children diagnosed with autism spectrum disorder: A cross-national study of the UK and China. (PhD Thesis), Queen's University Belfast, Belfast.

Liao, Y., Dillenburger, K., \& Buchanan, I. (2018). Does culture matter in ABA-based autism interventions? Parent and professional experiences in the UK and China. European Journal of Behavior Analysis, 19(1), 11-29. doi:10.1080/15021149.2017.1399657

Ling, C. Y. M., \& Mak, W. W. S. (2012). Coping with challenging behaviors of children with autism: Effectiveness of brief training workshop for frontline staff in special education settings. Journal of Intellectual Disability Research, 56(3), 258-269.

Liu, F., \& Chen, X. (2012). Efficacy observation of 41 autistic children's language training. [41 例孤独症儿童语言训练效果观察]. Today Nurse, 8, 91-92.

Liu, H., \& Li, Y. (2007). Application of applied behavior analysis in rehabilitation training for children with autism. [应用行为分析在自闭症儿童康复训练中的应用]. Chinese Journal of Special Education, 3(81), 33-37.

Lord, C., Rutter, M., DiLavore, P., Risi, S., Gotham, K., Bishop, S., . . Guthrie, W. (2012). Autism diagnostic observation schedule: Second edition (ADOS-2) Manual (Part I): Modules 1-4 (2nd ed.). Torrance, CA: Western Psychological Services.

Lovaas, O. I. (1987). Behavioral treatment and normal educational and intellectual functioning in young autistic children. Journal of Consulting and Clinical Psychology, 55(1), 3-9. doi:http://dx.doi.org/10.1037/0022-006X.55.1.3

Love, J. R., Carr, J. E., Almason, S. M., \& Petursdottir, A. I. (2009). Early and intensive behavioral intervention for autism: A survey of clinical practices. Research in Autism Spectrum Disorders, 3(2), 421-428. doi:10.1016/j.rasd.2008.08.008

Lu, J. P., Yang, Z. W., Shu, M. Y., \& Su, L. Y. (2004). Reliability, validity analysis of the Childhood Autism Rating Scale. Journal of Modern Medicine, 14(13), 119-123.

Lu, Y. Y., Tian, Q., Hao, Y. T., Jing, J., Lin, Y. D., \& Huang, D. Q. (2008). Reliability and validity for Chinese version of Pediatric Quality of Life Inventory, PedsQL 4.0. Journal of Sun Yat-sen University (Medicine Science), 29(3), 328-331. doi:10.13471/j.cnki.j.sun.yat-sen.univ(med.sci).2008.0103

Ma, J., Cui, Y., \& Zhang, X. (2016). Applied analysis of behavior treatment on children with autism. [行为治疗在孤独症儿童治疗中的应用分析]. Super Baby, 6, 76-76.

Ma, Y. (2017). A case study on the inappropriate behavior of a child with autism. [孤独症儿 童不良行为干预的个案研究]. Modern Vocational Education, 27, 60-60. doi:10.3969/j.issn.2096-0603.2017.27.041

Matson, J. L., Turygin, N. C., Beighley, J., \& Matson, M. L. (2012). Status of single-case research designs for evidence-based practice. Research in Autism Spectrum Disorders, 6(2), 931-938. doi:https://doi.org/10.1016/j.rasd.2011.12.008

McCabe, H. (2003). The beginnings of inclusion in the People's Republic of China. Research and Practice for Persons with Severe Disabilities, 28(1), 16-22. doi:10.2511/rpsd.28.1.16

McCabe, H. (2007). Parent advocacy in the face of adversity autism and families in the People's Republic of China. Focus on Autism and Other Developmental Disabilities, 22(1), 39-50. doi:10.1177/10883576070220010501 
McCabe, H. (2013). Bamboo shoots after the rain: Development and challenges of autism intervention in China. Autism: The International Journal of Research and Practice, 17(5), 510-526. doi:10.1177/1362361312436849

McCabe, H., \& Tian, H. (2001). Early intervention for children with autism in the people's republic of china: A focus on parent training. Journal of International Special Needs Education, 4, 39-43.

Moher, D., Liberati, A., Tetzlaff, J., Altman, D. G., \& Group, P. (2009). Preferred reporting items for systematic reviews and meta-analyses: The prisma statement. Annals of Internal Medicine, 151(4), 264-269. doi:10.7326/0003-4819-151-4-200908180-00135

Moher, D., Shamseer, L., Clarke, M., Ghersi, D., Liberati, A., Petticrew, M., . . Group, P.-P. (2015). Preferred reporting items for systematic review and meta-analysis protocols (PRISMA-P) 2015 statement. Systematic Reviews, 4(1), 1-25. doi:10.1186/20464053-4-1

National Bureau of Statistics. (2018). 2017 household income and consumer expenditure. [2017 年居民收入和消费支出情况]. Retrieved from http://www.stats.gov.cn/tjsj/zxfb/201801/t20180118_1574931.html

Nicholas, B. (2001). Introduction to documentary. Bloomington, IN: Indiana University Press.

Oppenheim, R. C. (1974). Effective teaching methods for autistic children, by Rosalind C. Oppenheim, with a foreword by Bernard Rimland. Springfield, Ill: Thomas.

Orinstein, A. J., Helt, M., Troyb, E., Tyson, K. E., Barton, M. L., Eigsti, I., . . . Fein, D. (2014). Intervention for optimal outcome in children and adolescents with a history of autism. Journal of Developmental and Behavioral Pediatrics, 35(4), 247-256. doi:10.1097/DBP.0000000000000037

Pang, Y., Lee, C. M., Wright, M., Shen, J., Shen, B., \& Bo, J. (2018). Challenges of case identification and diagnosis of autism spectrum disorders in China: A critical review of procedures, assessment, and diagnostic criteria. Research in Autism Spectrum Disorders, 53, 53-66. doi:10.1016/j.rasd.2018.06.003

Peng. S., \& Yu. Z. (2014). 89 cases of childhood autism language training effect analysis. [89 例儿童孤独症语训练效果分析]. Journal of Clinical Pathological Research, 35(5), 530-533.

Perry, A., Koudys, J., Prichard, A., \& Ho, H. (2019). Follow-up study of youth who received EIBI as young children. Behavior Modification, 43(2), 181-201. doi:10.1177/0145445517746916

Peters-Scheffer, N., Didden, R., Mulders, M., \& Korzilius, H. (2010). Low intensity behavioral treatment supplementing preschool services for young children with autism spectrum disorders and severe to mild intellectual disability. Research in Developmental Disabilities, 31(6), 1678-1684. doi:10.1016/j.ridd.2010.04.008

Psychosis Branch of Chinese Medical Association \& Brain Hospital of Nanjing Medical University. (1995). The Chinese Classification and the Diagnose Criterion of Mental Disorder (CCMD-2-R). [中国精神疾病分类方案与诊断标准]. Nanjing: Southeast University press. 
Qian, X. (2016). A case study of picture exchange communication system on highfunctioning children's requirement expression skill. [图片交换沟通系统改善高功能 自闭症需求表达技能的个案研究]. Journal of Suihua University, 36(1), 109-112.

Rapp, J. T., Cook, J. L., Nuta, R., Balagot, C., Crouchman, K., Jenkins, C., . . WattersWybrow, C. (2018). Further evaluation of a practitioner model for increasing eye contact in children with autism. Behavior Modification, 43(3), 389-412. doi: $10.1177 / 0145445518758595$

Reichow, B., Barton, E. E., Boyd, B. A., \& Hume, K. (2012). Early Intensive Behavioral Intervention (EIBI) for young children with autism spectrum disorders (ASD). The Cochrane Database of Systematic Reviews, 10, CD009260. doi:10.1002/14651858.CD009260.pub2

Reichow, B., \& Wolery, M. (2009). Comprehensive synthesis of early intensive behavioral interventions for young children with autism based on the UCLA young autism project model. Journal of Autism and Developmental Disorders, 39(1), 23-41. doi:10.1007/s10803-008-0596-0

Remington, B., Hastings, R. P., Kovshoff, H., Espinosa, F. d., Jahr, E., Brown, T., .. . Ward, N. (2007). Early intensive behavioral intervention: Outcomes for children with autism and their parents after two years. American Journal on Mental Retardation, 112(6), 418-438. doi:10.1352/0895-8017(2007)112[418:EIBIOF]2.0.CO;2

Sandieson, R. (2006). Pathfinding in the research forest: The Pearl Harvesting Method for effective information retrieval. Education and Training in Developmental Disabilities, 41(4), 401-409. doi:10.1017/CBO9780511666209.009

Sandieson, R. (2019). Pearl Harvesting Synonym Rings for comprehensive literature searching. Retrieved from https://sites.google.com/view/pearl-harvestingsearch/home

Schopler, E., Lansing, M. D., Reichler, R. J., \& Marcus, L. M. (2005). Examiner's manual of Psychoeducational Profile (3rd ed.). Austin, TX: Pro-ed Incorporation.

Schopler, E., Reichler, R. J., Bashford, A., Lansing, M. D., \& Marcus, L. M. (1990). Psychoeducational Profile-Revised (PEP-R). Austin, Texas: Pro-Ed.

Schopler, E., Reichler, R. J., \& Renner, B. R. (1986). The Childhood Autism Rating Scale (CARS): For diagnostic screening and classification of autism New York: Irvington.

Shao, W., Xu, S., \& Zhang, M. (2014). On communication training for low-functioning autism. [低功能自闭症儿童沟通能力训练的个案研究报告]. Journal of Chongqing Normal University (Philosophy and Social Science Edition), 5, 101-106.

Shen, M. (2017). Case study of functional assessment and treatment for behavior problems in autism. [自闭症儿童行为问题评估和干预的个案研究]. Modern Special Education (Higher Education), 3, 63-69.

Shenzhen Autism Society. (2013). Autistic people survey in southern China. Shenzhen: One Foundation.

Shi, P., Yu, Q., Guo, S., \& Li, Y. (2007). Applied behavioral analysis treatment for autism. [应用行为分析法治疗儿童孤独症]. Journal of Clinical Rehabilitative Tissue Engineering Research, 11(52), 10489-10491. 
Shook, G. L., \& Neisworth, J. T. (2005). Ensuring Appropriate Qualifications for Applied Behavior Analyst Professionals: The Behavior Analyst Certification Board AU Shook, Gerald L. Exceptionality, 13(1), 3-10. doi:10.1207/s15327035ex1301_2

Skinner, B. F. (1988). About behaviorism. New York: Random House USA Inc.

Smith, D. P., Hayward, D. W., Gale, C. M., Eikeseth, S., \& Klintwall, L. (2019). Treatment gains from early and intensive behavioral intervention (EIBI) are maintained 10 years later. Behavior Modification, O(0), 1-12. doi:10.1177/0145445519882895

Smith, T. (2001). Discrete trial training in the treatment of autism. Focus on Autism and Other Developmental Disabilities, 16(2), 86-92. doi:10.1177/108835760101600204

Smith, T., Groen, A. D., \& Wynn, J. W. (2000). Randomized trial of intensive early intervention for children with pervasive developmental disorder. American Journal of Mental Retardation, 105(4), 269-285. doi:10.1352/08958017(2000)105<0269:RTOIEI >2.0.CO;2

Sparrow, S., Ciccetti, D., \& Saulnier, C. (2016). Vineland III: Vineland adaptive behavior scales (3rd ed.). San Antonio, TX: Pearson Education.

Sun, L., \& Wei, X. (2011). Case study on self-injury of children with autism using functional behavior assessment approach. [以功能性行为评估为基础的自闭症儿童自伤行为 个案研究] Chinese Journal of Special Education, 138(12), 62-67.

Sun, X., Allison, C., Matthews, F. E., Sharp, S. J., Auyeung, B., Baron-Cohen, S., \& Brayne, C. (2013). Prevalence of autism in mainland Cina, Hongkong and Taiwan: A systematic review and meta-analysis. Molecular Autism, 4(7), 1-13. doi:10.1186/2040-2392-4-7

Tao, K. T. (1987). Brief report: Infantile autism in China. Journal of Autism and Developmental Disorders, 17(2), 289-296. doi:10.1007/BF01495062

United States Surgeon General. (1999, 1999). Mental health: A report of the surgeon general. Retrieved from https://www.loc.gov/item/2002495357/

Uono, S., \& Hietanen, J. K. (2015). Eye contact perception in the West and East: A crosscultural study. PLOS ONE, 10(2), e0118094. doi:10.1371/journal.pone.0118094

Wang, B., \& Kang, Y. S. (2011). Research review of early intensive behavior intervention. [自闭症儿童早期集中行为干预研究综述]. Journal of Educational Development, $12,52-55$.

Wang, F., Liu, L., Wang, S., Zhang, L., Ng, C. H., Ungvari, G. S., . . Xiang, Y. (2018). The prevalence of autism spectrum disorders in China: A comprehensive meta-analysis. International Journal of Bilogical Sciences, 14(7), 717-725. doi:10.7150/ijbs.24063

Wang, J., Hu, Y., Wang, Y., Qin, X., Xia, W., Sun, C., . . Wang, J. (2013). Parenting stress in Chinese mothers of children with autism spectrum disorders. Social Psychiatry and Psychiatric Epidemiology, 48(4), 575-582. doi:10.1007/s00127-012-0569-7

Wang, L. S. (2016). Preliminary study of pivotal response training on social communication skill of children with autism. [关键性技能训练对孤独症儿童社会技能疗效之初 探]. China Health Care Nutrition, 26(16), 35-36.

Wang, P. (2008). Effects of a parent training program on the interactive skills of parents of children with autism in China. Journal of Policy and Practice in Intellectual Disabilities, 5(2), 96-104. doi:10.1111/j.1741-1130.2008.00154.x 
Wang, S., Gong, Q., Zhang, G., Chen, S., He, L., Liu, F., \& Cui, R. (2011). Analysis on comprehensive intervention on behavioral abnormality of 81 autistic children. [81 例 儿童孤独症综合干预对行为异常的疗效分析]. Chinese Journal of Child Care, 19(5), 419-422.

Wang, S. G. (2016). On intervention of interference behaviors of children with autism based on the analysis of function. [基于功能分析的自闭症儿童干扰行为干预研究]. Journal of Suihua University, 36(10), 77-81.

Wang, Z., \& Yao, G. (2005). The comparative research on the quotation function of current three Chinese databases. [三大中文数据库引文功能比较]. The Library and Information Knowledge, 105, 61-65. doi:10.13366/j.dik.2005.03.017

Wechsler, D. (1989). Manual for the Wechsler Preschool and Primary Scale of Intelligencerevised. San Antonio: Psychological Corporation.

Wechsler, D. (1991). Wechsler Intelligence Scale for Children Third Edition manual. New York: The Psychological Corporation.

Wechsler, D. (2003). The Wechsler intelligence scale for children-Fourth edition. London: Pearson.

Wen, H. (2014). An exploration of private-owned autism service institutes in China. [民办孤 独症服务机构研究]. Disability Research, 2, 29-32.

Wong, C., Odom, S. L., Hume, K. A., Cox, A. W., Fettig, A., Kucharczyk, S., . . Schultz, T. R. (2015). Evidence-based practices for children, youth, and young adults with autism spectrum disorder: A comprehensive review. Journal of Autism and Developmental Disorders, 45(7), 1951-1966. doi:10.1007/s10803-014-2351-z

Xiao, Y., \& Yu, F. (2015). A case study on self-injurious behavior of an autistic child. [自闭 症儿童自伤行为干预个案研究]. Journal of Modern Special Education (Academic), $12,46-52$.

Xiong, N., Ji, C., Bo, H., Wang, X., Shi, J., Chen, Y., . . Li, Y. (2010). The effectiveness of applied behavior analysis intervention on clinic symptoms of children with autism and psychological condition of their mothers. [孤独症儿童临床症状及母亲心理状况的 应用行为分析干预效果]. Chinese Journal of Rehabilitation Medicine, 25(10), 564566.

Xu, G., Strathearn, L., Liu, B., \& Bao, W. (2018). Prevalence of autism spectrum disorder among US children and adolescents, 2014-2016. Journal of the American Medical Association, 319(1), 81-82. doi:10.1001/jama.2017.17812

Xu, S., Wang, J., Lee, G. T., \& Luke, N. (2017). Using self-monitoring with guided goal setting to increase academic engagement for a student with autism in an inclusive classroom in China. The Journal of Special Education, 51(2), 106-114. doi:10.1177/0022466916679980

Xu, Y., Yang, J., Yao, J., Chen, J., Zhuang, X., Wang, W., . . T., L. G. (2018). A pilot study of a culturally adapted early intervention for young children with autism spectrum disorders in China. Journal of Early Intervention, 40(1), 52-68. doi:10.1177/1053815117748408

Xu, Y., Yao, J., \& Yang, J. (2017). Application of Early Start Denver Model for early intervention on autistic children. [早期介入丹佛模式在孤独症儿童早期干预中的应 
用]. . Chinese Journal of Clinical Psychology, 25(1), 188-191.

doi:10.16128/j.cnki.1005-3611.2017.01.043

Yang, J., Zhu, Z., \& Cao, S. (2012). A functional behavior assessment-based case study of the seat-leaving behavior in the early childhood classroom. [基于功能性行为评估的 幼儿课堂离座行为个案研究]. Chinese Journal of Special Education, 11(149), 1824.

Yang, W., Xia, H., Wen, G., Liu, L., Fu, X., Lu, J., \& Li, H. (2015). Epidemiological investigation of suspected autism in children and implications for healthcare system: A mainstream kindergarten-based population study in Longhua District, Shenzhen. BMC Pediatrics, 15. doi:10.1186/s12887-015-0531-4

You, N., \& Yang, G. (2006). A review of studies on autism: Diagnosis and intervention. [自 闭症诊断与干预研究综述]. Chinese Journal of Special Education, 7(73), 26-31.

Zhang, L., Guo, W. B., \& Wang, T. Z. (2017). The development and application of Vineland Adaptive Behavior Scales. Journal of Modern Education (Higher Education), 11, $24-$ 38.

Zhang, Y. (2005). Case study on music therapy intervention to behavior training for a highfunction autistic child. [音乐治疗干预高功能孤独症儿童行为训练的个案研究]. Chinese Journal of Special Education, 8(62), 38-43.

Zheng, R., \& Li, X. (2017). A case study on training effect of a speechless autistic child's expression of demand. [无语自闭症儿童表达需求训练效应的个案研究]. Journal of Lingnan Normal University, 38(2), 37-44.

Zheng, Y., Maude, S. P., Brotherson, M. J., \& Merritts, A. (2016). Early childhood intervention in China from the families' perspective. International Journal of Disability, Development and Education, 63(4), 431-449. doi:10.1080/1034912X.2015.1124988

Zhong, C. (2016). A case study of aggressive behavior in children with autism. [对自闭症儿 童攻击性行为的个案研究]. Journal of Educational Institution of Jilin Province, 32(2), 37-39. doi:10.16083/j.cnki.1671-1580.2016.02.007

Zhou, B., Xu, Q., Li, H., Zhang, Y., Wang, Y., Rogers, S. J., \& Xu, X. (2018). Effects of parent-implemented Early Start Denver Model intervention on chinese toddlers with autism spectrum disorder: A non-randomized controlled trial. Autism Research, 11(4), 654-666. doi:10.1002/aur.1917

Zhou, H., Xu, X., Yan, W., Zou, X., Wu, L., Luo, X., . . LATENT-NHC. (2018). Prevalence of autism spectrum disorder in China: A nationwide multi-centre population-based study among children aged 6 to 12 years. The Lancet.

Zhou, W. Z., Ye, A. Y., Sun, Z. K., Tian, H. H., Pu, T. Z., Wu, Y. Y., . . Wei, L. (2014). Statistical analysis of twenty years (1993 to 2012) of data from Mainland China's first intervention center for children with autism spectrum disorder. Molecular Autism, 5, 52. doi:10.1186/2040-2392-5-52

Zhu, D. (2013). Applied behavior analysis on the food selectivity of children with autism. [应 用行为分析方法矫正自闭症儿童偏食]. Social Welfare, 7, 41-42.

Zou, B., Ke, X., Hong, S., Hang, Y., Chen, Y., Chen, X., \& Wang, M. (2008). Analysis on the efficiency of discrete trial training for autistic children used by parents. [家长应用 
回合式教学法训练孤独障碍儿童的疗效研究]. Chinese Mental Health Journal, 22(9), 634-665.

Table 1: Breakdown of excluded and included articles at full-text screening level

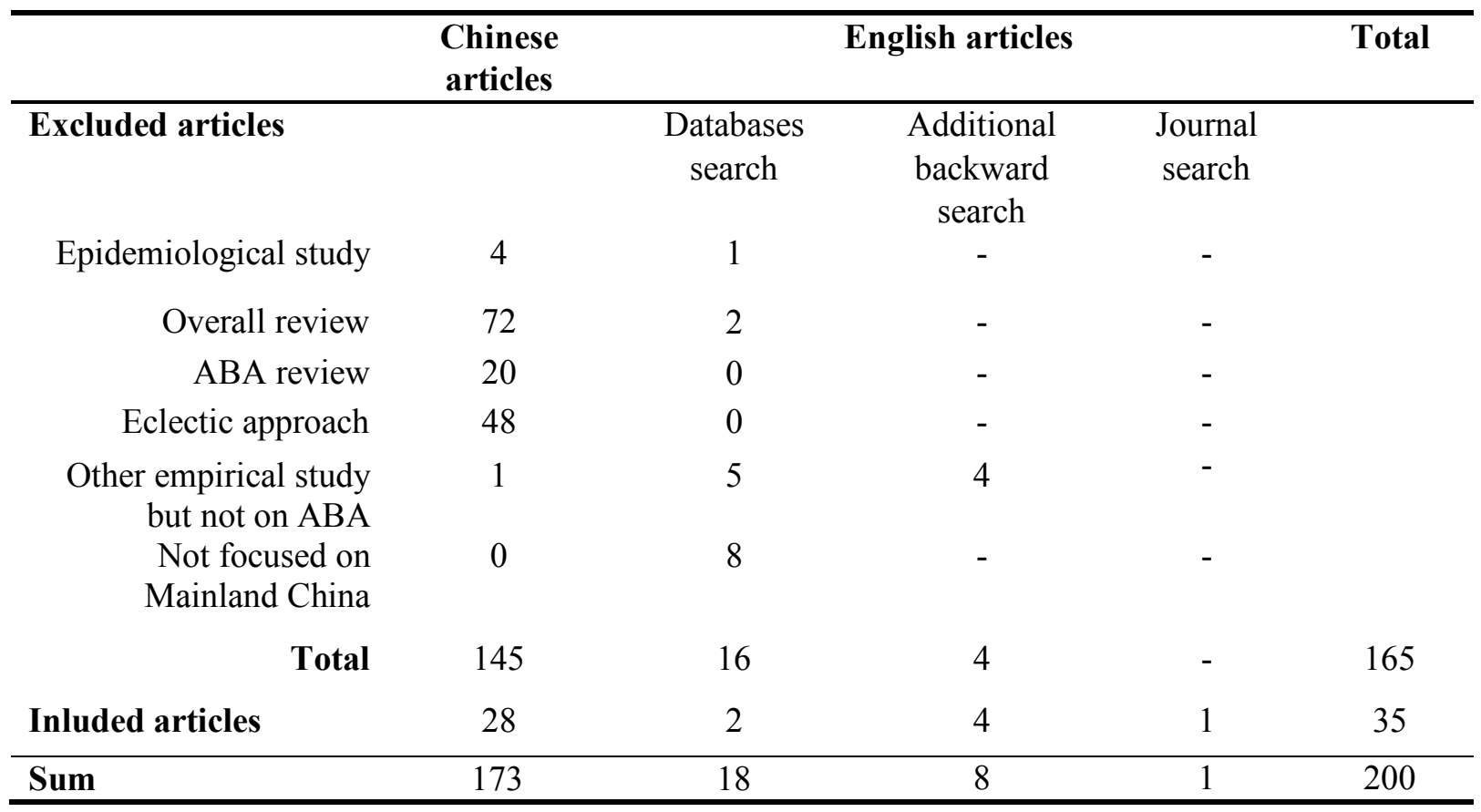



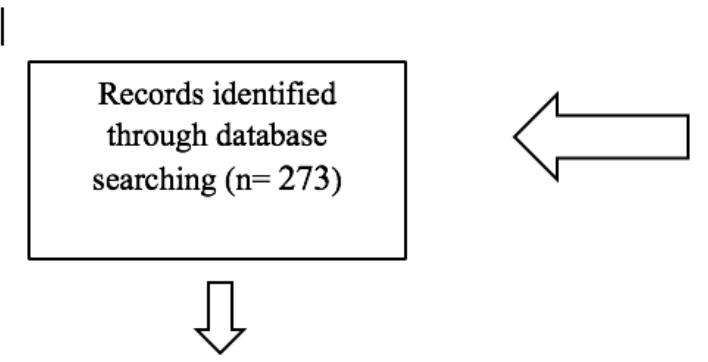

\begin{tabular}{|c|c|c|c|}
\hline \multicolumn{4}{|c|}{ Database and Journal Searchers (n=21) } \\
\hline ERIC & 4 & SCOPUS & 38 \\
\hline Web of Science & 18 & PubMed & 15 \\
\hline $\begin{array}{c}\text { ProQuest Social } \\
\text { Science }\end{array}$ & 86 & $\begin{array}{c}\text { 16 Journal } \\
\text { Searches }\end{array}$ & 112 \\
\hline Sum & \multicolumn{3}{|c|}{273} \\
\hline
\end{tabular}
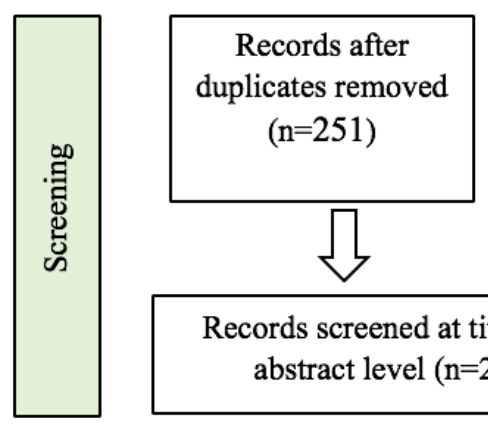

Additional records identified through backward literature search $(\mathrm{n}=8)$

Records screened at title and abstract level $(n=27)$

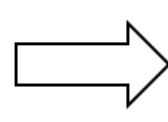

Records excluded ( $n=232)$, with reasons of title/abstract not relevant
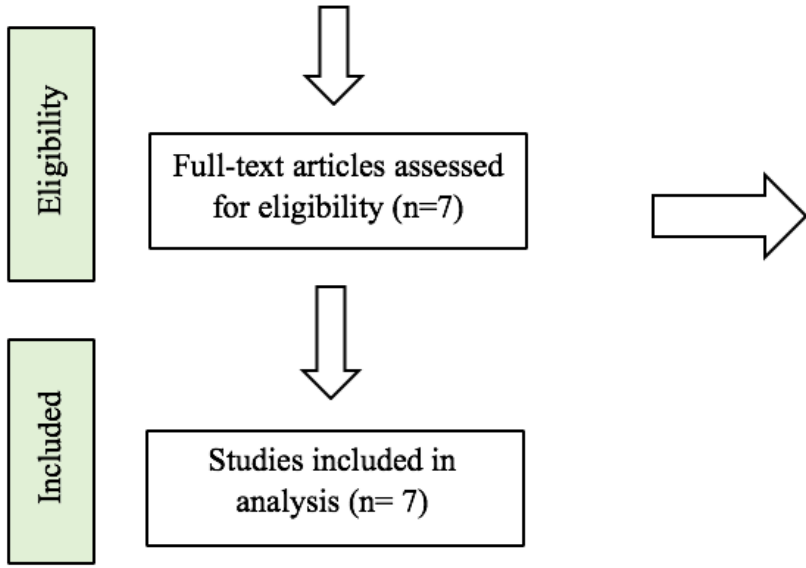

Studies included in analysis $(\mathrm{n}=7)$

Figure 1: PRISMA chart of English articles 

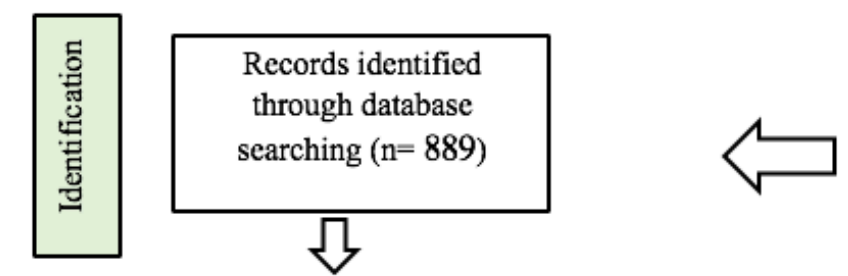

\begin{tabular}{|c|c|}
\hline \multicolumn{2}{|c|}{ Database $(\mathrm{n}=3)$} \\
\hline CNKI & 653 \\
\hline VIP & 154 \\
\hline Wanfang & 82 \\
\hline Sum & 889 \\
\hline
\end{tabular}
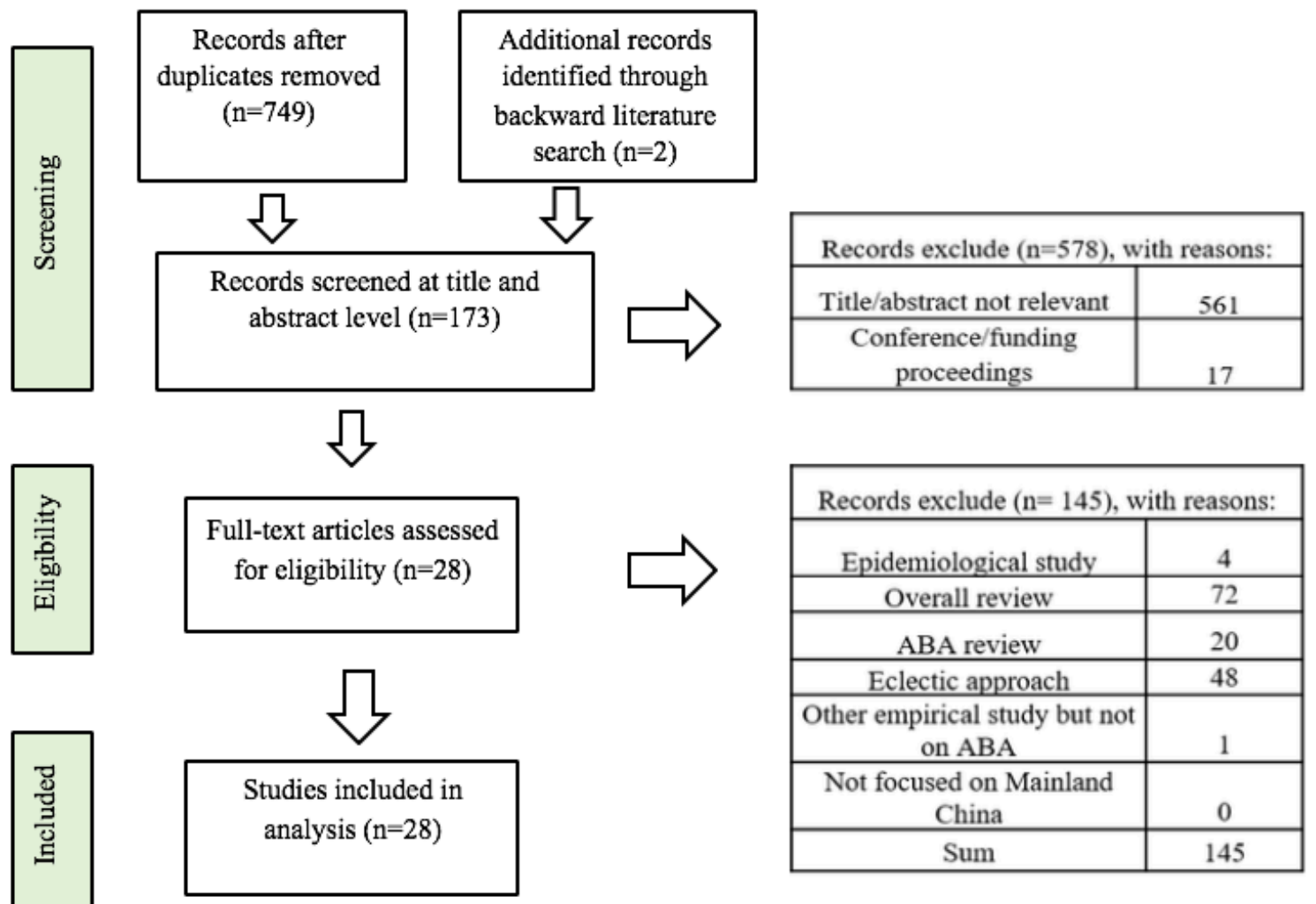

\begin{tabular}{|c|c|}
\hline \multicolumn{2}{|c|}{ Records exclude ( $\mathrm{n}=145)$, with reasons: } \\
\hline Epidemiological study & 4 \\
\hline Overall review & 72 \\
\hline ABA review & 20 \\
\hline Eclectic approach & 48 \\
\hline $\begin{array}{c}\text { Other empirical study but not } \\
\text { on ABA }\end{array}$ & 1 \\
\hline $\begin{array}{c}\text { Not focused on Mainland } \\
\text { China }\end{array}$ & 0 \\
\hline Sum & 145 \\
\hline
\end{tabular}

Figure 2: PRISMA chart of Chinese articles 


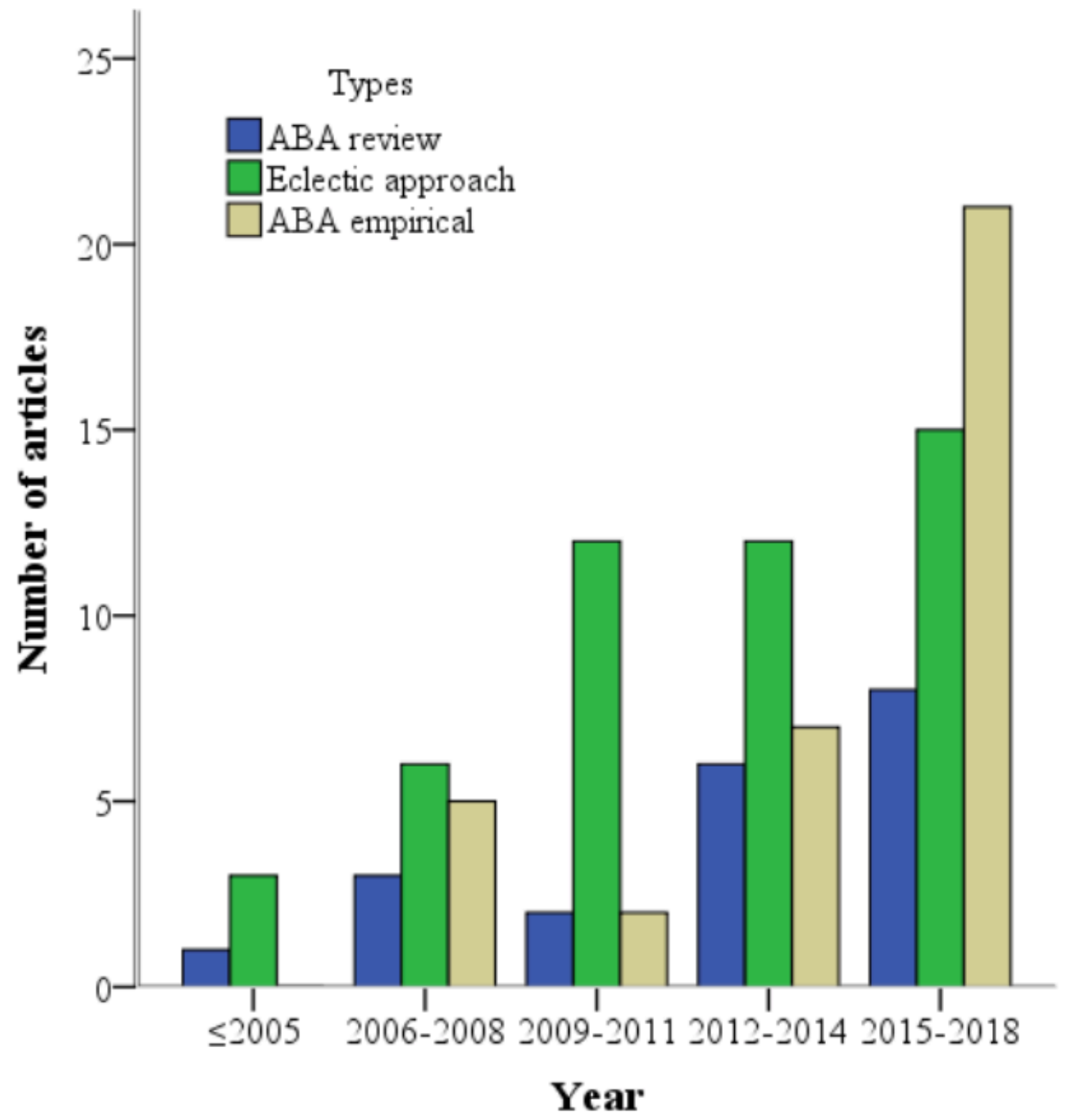

Figure 3 Research trend related to ABA and autism in mainland China 
Table 2: Analysis of articles included in systematic reviews

\begin{tabular}{|c|c|c|c|c|c|c|c|c|}
\hline Year & Authors & Location & $\begin{array}{l}\text { Measurement } \\
\text { tools }\end{array}$ & Participants & Outcomes & $\begin{array}{l}\text { Research } \\
\text { method }\end{array}$ & Diagnosis & $\begin{array}{l}\text { Length of } \\
\text { program }\end{array}$ \\
\hline 2018 & Xu et al. & $\begin{array}{l}\text { South east } \\
\text { China }\end{array}$ & $\begin{array}{l}\text { PEP-3; } \\
\text { CARS }\end{array}$ & $\begin{array}{l}\mathbf{N}=\mathbf{3 6} ; \\
\mathbf{1 6} \text { boys, in } \\
\text { experiment group } \\
\text { (age }=47.5 \text { mo); } \\
\mathbf{2 0} \text { children ( } 18 \text { boys } \\
\text { and } 2 \text { girls) in } \\
\text { control group (e } \\
\text { age }=42.9 \text { mo) }\end{array}$ & $\begin{array}{l}\text { Decrease in } \\
\text { autism } \\
\text { symptoms and } \\
\text { improved } \\
\text { severity } \\
\text { categorization }\end{array}$ & $\begin{array}{l}\text { Within- and } \\
\text { between- } \\
\text { group } \\
\text { design. }\end{array}$ & $\begin{array}{l}\text { CARS \& } \\
\text { DSM-5 }\end{array}$ & $\begin{array}{l}8 \text { weeks }(1 \\
\text { hr per day; } \\
5 \text { hrs per } \\
\text { week })\end{array}$ \\
\hline 2018 & $\begin{array}{l}\text { Liao, } \\
\text { Dillenburg } \\
\text { er \& } \\
\text { Buchanan }\end{array}$ & $\begin{array}{l}\text { A city at } \\
\text { Northern } \\
\text { Ireland; Beijing } \\
\text { and a city at } \\
\text { Southern China }\end{array}$ & $\begin{array}{l}\text { Self- } \\
\text { administered } \\
\text { interviews }\end{array}$ & $\begin{array}{l}\mathrm{N}=15 \\
10 \text { professionals and } \\
5 \text { parents (age } \\
\text { unknown) }\end{array}$ & $\begin{array}{l}\text { Application of } \\
\text { behavior } \\
\text { analyisis } \\
\text { services vary } \\
\text { widely across } \\
\text { cultures }\end{array}$ & $\begin{array}{l}\text { Semi- } \\
\text { structured } \\
\text { interview }\end{array}$ & N/A & $\mathrm{N} / \mathrm{A}$ \\
\hline 2017 & $\begin{array}{l}\text { Xu, Yao \& } \\
\text { Yang }\end{array}$ & $\begin{array}{l}\text { Hangzhou \& } \\
\text { Xiamen/ East } \\
\text { coast of China }\end{array}$ & CARS & $\begin{array}{l}\mathrm{N}=36 \\
16 \text { children (15 boys } \\
\text { and } 1 \text { girl ) in } \\
\text { experiment; } 20 \\
\text { children ( } 19 \text { boys } \\
\text { and } 1 \text { girl ) in } \\
\text { control }\end{array}$ & $\begin{array}{l}\text { Improved } \\
\text { social } \\
\text { interaction, } \\
\text { communicatio } \\
\mathrm{n} \text { and } \\
\text { emotional } \\
\text { expression. }\end{array}$ & $\begin{array}{l}\text { Within- and } \\
\text { between- } \\
\text { group } \\
\text { design. }\end{array}$ & $\begin{array}{l}\text { CARS \& } \\
\text { DSM-5 }\end{array}$ & $\begin{array}{l}8 \text { weeks } \\
(80 \\
\text { sessions })\end{array}$ \\
\hline
\end{tabular}




\begin{tabular}{|c|c|c|c|c|c|c|c|c|}
\hline 2017 & $\begin{array}{l}\text { Lee, Feng, } \\
\text { Xu, \& Jin }\end{array}$ & Central China & $\begin{array}{l}\text { Child: } \\
\text { Behavioral } \\
\text { observation }\end{array}$ & $\begin{array}{l}\mathrm{N}=5 \\
4 \text { boys and one girl } \\
(3-6 \text { years of age })\end{array}$ & $\begin{array}{l}\text { Improved } \\
\text { object- } \\
\text { substitution } \\
\text { symbolic play } \\
\text { skills }\end{array}$ & $\begin{array}{l}\text { Multiple } \\
\text { probe } \\
\text { design }\end{array}$ & $\begin{array}{l}\text { (ADOS-2; } \\
\text { Lord et al., } \\
\text { 2012) and } \\
\text { DSM-5; } \\
\text { ADOS-2 and } \\
\text { DSM-IV } \\
\text { (APA, 1994). }\end{array}$ & $\begin{array}{l}1 \mathrm{hr} \text { per } \\
\text { day, four } \\
\text { days per } \\
\text { week. } \\
\text { Duration } \\
\text { not } \\
\text { reported }\end{array}$ \\
\hline 2017 & $\begin{array}{l}\text { Xu, Wang, } \\
\text { Lee \& } \\
\text { Luke }\end{array}$ & $\begin{array}{l}\text { Western China/ } \\
\text { An inland city }\end{array}$ & $\begin{array}{l}\text { Child: } \\
\text { Behavioral } \\
\text { observation* } \\
*\end{array}$ & A 9 year-old boy & $\begin{array}{l}\text { Increased } \\
\text { academic } \\
\text { engagement }\end{array}$ & $\begin{array}{l}\text { Changing } \\
\text { criterion } \\
\text { design }\end{array}$ & $\begin{array}{l}\text { CARS \& } \\
\text { WISC-IV } \\
\text { (Wechsler, } \\
\text { 2003) }\end{array}$ & $\begin{array}{l}2915- \\
\text { minites } \\
\text { sessions }\end{array}$ \\
\hline 2017 & $\mathrm{Ma}^{*}$ & Inner Mongolia & Child: PEP-3 & $\begin{array}{l}\text { A } 10.83 \text { year-old } \\
\text { boy }\end{array}$ & $\begin{array}{l}\text { Reduced } \\
\text { inappropriate } \\
\text { behavior }\end{array}$ & $\begin{array}{l}\text { Single case } \\
\text { study, only } \\
\text { baseline } \\
\text { data, no } \\
\text { intervention } \\
\text { data. }\end{array}$ & $\mathrm{N} / \mathrm{R}$ & 23 days \\
\hline 2017 & $\mathrm{He}$ & $\begin{array}{l}\text { Nanchang city, } \\
\text { Jiangxi } \\
\text { province/ } \\
\text { Southern China }\end{array}$ & $\begin{array}{l}\text { Child: } \\
\text { Behavioral } \\
\text { observation }\end{array}$ & $\begin{array}{l}5 \text { children (other } \\
\text { informationa } \\
\text { unknown) }\end{array}$ & $\begin{array}{l}\text { ABA-based } \\
\text { intervention } \\
\text { helps improve } \\
\text { children's } \\
\text { emotional } \\
\text { behavior. }\end{array}$ & $\begin{array}{l}\text { Case study } \\
\text { without } \\
\text { quantitative } \\
\text { data }\end{array}$ & $\mathrm{N} / \mathrm{R}$ & $\begin{array}{l}3-12 \\
\text { months }\end{array}$ \\
\hline 2017 & $\begin{array}{l}\text { Zheng \& } \\
\text { Li }\end{array}$ & NR & $\begin{array}{l}\text { Child: } \\
\text { Behavioral } \\
\text { observation }\end{array}$ & A 10 year-old child & $\begin{array}{l}\text { The } \\
\text { combination } \\
\text { of PECS and } \\
\text { DTT reduced } \\
\text { child's } \\
\text { maladaptive }\end{array}$ & $\begin{array}{l}\text { Experiment } \\
\text { al design: } \\
\text { Single case } \\
\text { design, A- } \\
\text { B-A design }\end{array}$ & $\begin{array}{l}\text { Self - } \\
\text { administrator } \\
\text { ed assessment } \\
\text { tool and } \\
\text { diagnosis }\end{array}$ & $\begin{array}{l}20 \text { days } \\
\text { (twice a } \\
\text { day, } 30 \\
\text { min per } \\
\text { training } \\
\text { session) }\end{array}$ \\
\hline
\end{tabular}




\begin{tabular}{|c|c|c|c|c|c|c|c|c|}
\hline & & & & & $\begin{array}{l}\text { behavior and } \\
\text { increased } \\
\text { child's } \\
\text { demand } \\
\text { behavior }\end{array}$ & & $\begin{array}{l}\text { confirmed by } \\
\text { a hospital }\end{array}$ & \\
\hline 2017 & Shen & Guangxi & $\begin{array}{l}\text { Child: } \\
\text { Behavior } \\
\text { observation }\end{array}$ & A 7 year-old boy & $\begin{array}{l}\text { Reduced } \\
\text { inappropriate } \\
\text { behavior }\end{array}$ & $\begin{array}{l}\text { Single case } \\
\text { reversal } \\
\text { design, } \\
\text { ABAB }\end{array}$ & $\mathrm{N} / \mathrm{R}$ & 13 weeks \\
\hline 2016 & $\begin{array}{l}\text { Hu, Chen \& } \\
\text { Zhen }\end{array}$ & $\begin{array}{l}\text { Beijing/Nonrthe } \\
\text { rn China }\end{array}$ & $\begin{array}{l}\text { Child: } \\
\text { Behavioral } \\
\text { observation }\end{array}$ & A 4 year-old boy & $\begin{array}{l}\text { Improved } \\
\text { structured } \\
\text { play and joint } \\
\text { attention }\end{array}$ & $\begin{array}{l}\text { A-B-A-B } \\
\text { design }\end{array}$ & $\begin{array}{l}\text { An } \\
\text { authorative } \\
\text { hospital }\end{array}$ & 21 days \\
\hline 2016 & $\begin{array}{l}\text { Hu, Liu, } \\
\text { Fan \& Zhen }\end{array}$ & $\begin{array}{l}\text { Beijing/Nonrthe } \\
\text { rn China }\end{array}$ & $\begin{array}{l}\text { Child: } \\
\text { Behavioral } \\
\text { observation; } \\
\text { WPPSI-R } \\
\text { (participant } \\
\text { selection) }\end{array}$ & $\begin{array}{l}\text { Two } 5.6 \text { year-old } \\
\text { boy and one } 5 \text { year } \\
\text { old girl }\end{array}$ & $\begin{array}{l}\text { Speech- } \\
\text { generative } \\
\text { device to } \\
\text { improove } \\
\text { speech }\end{array}$ & $\begin{array}{l}\text { Multiple } \\
\text { baseline } \\
\text { design }\end{array}$ & $\begin{array}{l}\text { An } \\
\text { authorative } \\
\text { hospital \& } \\
\text { WPPSI-R }\end{array}$ & $\begin{array}{l}38 \text { trials } \\
\text { on average } \\
(10 \text { min } \\
\text { per trial } \\
\text { per day) }\end{array}$ \\
\hline 2016 & Wang L.* & $\begin{array}{l}\text { A city at Hebei } \\
\text { province/ } \\
\text { North-central } \\
\text { China }\end{array}$ & $\begin{array}{l}\text { Child: } \\
\text { CARS; } \\
\text { ATEC (Lu, } \\
\text { Yang, Shu, \& } \\
\text { Su, 2004); } \\
\text { Autism Child } \\
\text { Development } \\
\text { Assessment } \\
\text { Form (China } \\
\text { Disabled } \\
\text { Persons' } \\
\text { Federation, } \\
\text { 2009) }\end{array}$ & $\begin{array}{l}3 \text { children reported } \\
\text { between 1-6 year- } \\
\text { old }\end{array}$ & $\begin{array}{l}\text { Pivotal } \\
\text { Response } \\
\text { Training is } \\
\text { effective for } \\
\text { children with } \\
\text { autism }\end{array}$ & $\begin{array}{l}\text { Reprted as } \\
\text { empirical } \\
\text { study by } \\
\text { the author: } \\
\text { Multiple } \\
\text { baseline } \\
\text { design } \\
\text { across } \\
\text { particiapnts } \\
\text { though } \\
\text { quantitative } \\
\text { data was } \\
\text { not shown }\end{array}$ & $\begin{array}{l}\text { Chinese } \\
\text { Classification } \\
\text { of Mental } \\
\text { Diseases, } 3 \mathrm{rd} \\
\text { (CCMD-3, } \\
\text { Chen, 2002) }\end{array}$ & 1.5 month \\
\hline
\end{tabular}




\begin{tabular}{|c|c|c|c|c|c|c|c|c|}
\hline 2016 & Zhong & $\begin{array}{l}\text { Heilongjiang } \\
\text { province/ } \\
\text { North-eastern } \\
\text { China }\end{array}$ & $\begin{array}{l}\text { Child: } \\
\text { Behavioral } \\
\text { observation }\end{array}$ & A 11 year-old boy & $\begin{array}{l}\text { Aggressive } \\
\text { behavior } \\
\text { reduced }\end{array}$ & $\begin{array}{l}\text { Case study } \\
\text { without } \\
\text { quantitative } \\
\text { data }\end{array}$ & $\mathrm{N} / \mathrm{R}$ & 3 months \\
\hline 2016 & Wang & $\begin{array}{l}\text { Guanghzou, } \\
\text { Guangdong } \\
\text { province/ } \\
\text { Southern China }\end{array}$ & $\begin{array}{l}\text { Child: } \\
\text { Behavior } \\
\text { observation }\end{array}$ & A 10 year-old child & $\begin{array}{l}\text { Disruptive } \\
\text { behavior } \\
\text { reduced }\end{array}$ & $\begin{array}{l}\text { Single case } \\
\text { study, ABA } \\
\text { design }\end{array}$ & $\begin{array}{l}\mathrm{N} / \mathrm{R}, \text { only } \\
\text { mentioned } \\
\text { diagnosed by } \\
\text { a hospital }\end{array}$ & 20 days \\
\hline 2016 & Han* & $\begin{array}{l}\text { Chongqing } \\
\text { city/South- } \\
\text { western China }\end{array}$ & $\begin{array}{l}\text { Child: } \\
\text { Behavioral } \\
\text { observation }\end{array}$ & A 10 year-old boy & $\begin{array}{l}\text { Disruptive } \\
\text { behavior at } \\
\text { classroom } \\
\text { reduced }\end{array}$ & $\begin{array}{l}\text { Case } \\
\text { studies } \\
\text { without } \\
\text { quantitative } \\
\text { data }\end{array}$ & $\mathrm{N} / \mathrm{R}$ & NR \\
\hline 2016 & $\begin{array}{l}\text { Huo, Liu } \\
\& \mathrm{Hu}\end{array}$ & $\begin{array}{l}\text { Beijing/Nonrthe } \\
\text { rn China }\end{array}$ & $\begin{array}{l}\text { Child: } \\
\text { Behavioral } \\
\text { observation }\end{array}$ & $\begin{array}{l}\text { Three } 7.33 \text { year-old } \\
\text { boy (Gender not } \\
\text { reported) }\end{array}$ & $\begin{array}{l}\text { Facial } \\
\text { expression } \\
\text { recognition } \\
\text { improved }\end{array}$ & $\begin{array}{l}\text { Single case } \\
\text { study } \\
\text { (ABA } \\
\text { design) }\end{array}$ & NR & $\begin{array}{l}\text { More than } \\
51 \text { classes } \\
\text { across } \\
\text { several } \\
\text { months } \\
\text { (Length } \\
\text { not } \\
\text { reported) }\end{array}$ \\
\hline 2016 & $\begin{array}{l}\text { Ma, Cui \& } \\
\text { Zhang* }\end{array}$ & $\begin{array}{l}\text { Ningxia/An } \\
\text { autonomous } \\
\text { region in North- } \\
\text { central China }\end{array}$ & $\begin{array}{l}\text { Child: } A B C \\
\text { assessment }\end{array}$ & $\begin{array}{l}\mathrm{N}=90 \\
68 \text { boys and } 22 \text { girls } \\
\text { (Age: } 2.3 \pm 1.6 \text { ) }\end{array}$ & $\begin{array}{l}\text { Language } \\
\text { ability, } \\
\text { independent } \\
\text { living skill, } \\
\text { social } \\
\text { communicatio } \\
\text { n, physical } \\
\text { activity and } \\
\text { cognitive } \\
\text { ability } \\
\text { improved }\end{array}$ & $\begin{array}{l}\text { Within } \\
\text { group } \\
\text { design }\end{array}$ & DSM-IV & NR \\
\hline
\end{tabular}




\begin{tabular}{|c|c|c|c|c|c|c|c|c|}
\hline 2016 & Qian* & $\begin{array}{l}\text { Shanghai/ } \\
\text { Eastern China }\end{array}$ & $\begin{array}{l}\text { Child: } \\
\text { Behavior } \\
\text { observation }\end{array}$ & One 8 year-old boy & $\begin{array}{l}\text { language } \\
\text { expressions } \\
\text { improved }\end{array}$ & $\begin{array}{l}\text { Single case } \\
\text { study, ABA } \\
\text { design }\end{array}$ & $\begin{array}{l}\text { Wechsler } \\
\text { Intelligence } \\
\text { Test and } \\
\text { Childhood } \\
\text { Development } \\
\text { al } \\
\text { Assessment } \\
\text { (WPPSI) }\end{array}$ & $\begin{array}{l}20 \\
\text { sessions } \\
(35 \\
\text { min/sessio } \\
\mathrm{n}, 3 \text { times } \\
\text { per week) }\end{array}$ \\
\hline 2015 & $\begin{array}{l}\mathrm{Hu}, \mathrm{Xu}, \\
\mathrm{Xu}, \& \\
\text { Feng }\end{array}$ & $\begin{array}{l}\text { Chongqing } \\
\text { city/South- } \\
\text { eastern China }\end{array}$ & $\begin{array}{l}\text { Child: } \\
\text { Reported IQ } \\
\text { score but did } \\
\text { not mention } \\
\text { the exact } \\
\text { measurement } \\
\text { tool; Self- } \\
\text { administered } \\
\text { Curriculum } \\
\text { Assessment } \\
\text { Tool on } \\
\text { Children with } \\
\text { Autism }\end{array}$ & $\begin{array}{l}\text { Three } 6.8 \text { year-old } \\
\text { boys }\end{array}$ & $\begin{array}{l}\text { Students } \\
\text { progressed }\end{array}$ & $\begin{array}{l}\text { Multiple } \\
\text { baseline } \\
\text { design } \\
\text { across } \\
\text { subjects } \\
\text { (ABA } \\
\text { design) }\end{array}$ & $\mathrm{N} / \mathrm{R}$ & $\begin{array}{l}\text { Two case } \\
\text { undertook } \\
11 \text { week } \\
\text { and the } \\
\text { other case } \\
\text { undertook } \\
9 \text { weeks }\end{array}$ \\
\hline 2015 & $\begin{array}{l}\text { Ding, } \\
\text { Zhong, } \\
\text { Cheng, \& } \\
\text { Jiang }\end{array}$ & $\begin{array}{l}\text { City unkown, } \\
\text { Hunan } \\
\text { province/ } \\
\text { Southern China }\end{array}$ & $\begin{array}{l}\text { Parents: The } \\
\text { Pediatric } \\
\text { Quality } \\
\text { of Life } \\
\text { Inventory } \\
\text { Measurement } \\
\text { Models, } \\
\text { (PedsQL TM , } \\
\text { Lu Tian, Hao, } \\
\text { Jing, Lin, } \\
\text { Huang, 2008) }\end{array}$ & $\begin{array}{l}\mathrm{N}=132 \\
58 \text { boys and } 8 \text { girls } \\
\text { (average age: } \\
2.9 \pm 1.5 \text { ) in } \\
\text { experiment group; } \\
58 \text { boys and } 8 \text { girls } \\
\text { in control group } \\
\text { (average } \\
\text { age: } 3.1 \pm 1.3 \text { ). }\end{array}$ & $\begin{array}{l}\text { Children have } \\
\text { poor quality } \\
\text { of life; ABA } \\
\text { improves } \\
\text { child's quality } \\
\text { of life }\end{array}$ & $\begin{array}{l}\text { Within } \\
\text { group } \\
\text { design and } \\
\text { between- } \\
\text { group } \\
\text { design }\end{array}$ & DSM-IV & 3 months \\
\hline
\end{tabular}




\begin{tabular}{|c|c|c|c|c|c|c|c|c|}
\hline 2015 & Xiao \& Yu & $\begin{array}{l}\text { Guangzhou, } \\
\text { Guangdong } \\
\text { province/ } \\
\text { Southern China }\end{array}$ & $\begin{array}{l}\text { Child: } \\
\text { Behavior } \\
\text { observation }\end{array}$ & A 11 year-old & $\begin{array}{l}\text { Disruptive } \\
\text { behavior } \\
\text { reduced }\end{array}$ & $\begin{array}{l}\text { Single case } \\
\text { design, } \\
\text { ABA } \\
\text { design }\end{array}$ & $\begin{array}{l}\mathrm{N} / \mathrm{R} \text {, only } \\
\text { mentioned } \\
\text { diagnosed by } \\
\text { a hospital }\end{array}$ & 12 weeks \\
\hline 2014 & $\begin{array}{l}\text { Zhou, Ye, } \\
\text { Sun,Tian, } \\
\text { Pu, Wu, } \\
\text { Wang, } \\
\text { Zhao, Lu, } \\
\text { Yang \& } \\
\text { Wei }\end{array}$ & $\begin{array}{l}\text { Beijing/ } \\
\text { Northern China }\end{array}$ & NR & $\begin{array}{l}\mathrm{N}=2,222 \\
\text { (gender unkown, } 6 \\
\text { years of age and } \\
\text { under); } \\
100 \text {-member centres } \\
\text { of Heart Alliance } \\
\text { Autism Network }\end{array}$ & $\begin{array}{l}\text { Increased } \\
\text { number of } \\
\text { hospitals } \\
\text { making ASD } \\
\text { diagnoses; } \\
\text { increased } \\
\text { service } \\
\text { centers } \\
\text { between } 1993 \\
\text { and 2012; } \\
\text { Average age } \\
\text { of first autism } \\
\text { diagnosis } \\
\text { decreased; } \\
\text { limited } \\
\text { number of } \\
\text { hospitals and } \\
\text { intervention } \\
\text { centers in } \\
\text { under- } \\
\text { developed } \\
\text { regions. }\end{array}$ & $\begin{array}{l}\text { Empirical } \\
\text { study: } \\
\text { Students' } \\
\text { registration } \\
\text { data and } \\
\text { survey }\end{array}$ & $\begin{array}{l}\text { ADI-R/DSM- } \\
\text { IV-TR }\end{array}$ & NR \\
\hline 2014 & Hu \& Fan & $\begin{array}{l}\text { Beijing/ } \\
\text { Northern China }\end{array}$ & $\begin{array}{l}\text { Child: } \\
\text { WPPSI-R; } \\
\text { PEP-3 }\end{array}$ & A 4.25 year-old boy & $\begin{array}{l}\text { Child's mand } \\
\text { behavior } \\
\text { improved and } \\
\text { aggressive } \\
\text { behavior } \\
\text { decreased }\end{array}$ & $\begin{array}{l}\text { Multiple } \\
\text { baseline } \\
\text { design } \\
\text { across } \\
\text { settings, } \\
\text { AB design }\end{array}$ & $\mathrm{N} / \mathrm{R}$ & 3 months \\
\hline
\end{tabular}




\begin{tabular}{|c|c|c|c|c|c|c|c|c|}
\hline 2014 & $\begin{array}{l}\text { Shao, Xu } \\
\text { \& Zhang }\end{array}$ & $\begin{array}{l}\text { Chongqing city/ } \\
\text { West-southern } \\
\text { China }\end{array}$ & $\begin{array}{l}\text { Child: } \\
\text { Behavioral } \\
\text { observation }\end{array}$ & A 2.5 year-old boy & $\begin{array}{l}\text { Communicati } \\
\text { on skills } \\
\text { improved }\end{array}$ & $\begin{array}{l}\text { Case study } \\
\text { without } \\
\text { quantitative } \\
\text { data }\end{array}$ & $\mathrm{N} / \mathrm{R}$ & $\begin{array}{l}\text { One year, } \\
\text { one hour } \\
\text { per week, } \\
4 \text { times per } \\
\text { week }\end{array}$ \\
\hline 2013 & $\begin{array}{l}\text { Duan \& } \\
\text { Niu* }\end{array}$ & $\begin{array}{l}\text { City unkown, } \\
\text { Henan } \\
\text { province/ } \\
\text { Northern China }\end{array}$ & $\begin{array}{l}\text { Child: The } \\
\text { Autism } \\
\text { Behavior } \\
\text { Checklist } \\
\text { (ABC) }\end{array}$ & $\begin{array}{l}\mathrm{N}=48 \\
26 \text { boys and } 22 \text { girls } \\
\text { (average age } \\
5.9 \pm 1.3 \text { ) }\end{array}$ & $\begin{array}{l}\text { Sensory } \\
\text { issues, social } \\
\text { communicatio } \\
\text { n, physical } \\
\text { activity, } \\
\text { language } \\
\text { ability and } \\
\text { self- } \\
\text { independent } \\
\text { skills } \\
\text { improved } \\
\end{array}$ & $\begin{array}{l}\text { Within } \\
\text { group } \\
\text { design }\end{array}$ & $\mathrm{N} / \mathrm{R}$ & 6 months \\
\hline 2013 & Zhu* & $\begin{array}{l}\text { Hangzhou, } \\
\text { Zhejiang } \\
\text { province/ } \\
\text { Eastern China } \\
\end{array}$ & $\begin{array}{l}\text { Child: } \\
\text { Behavioral } \\
\text { observation }\end{array}$ & $\begin{array}{l}\text { One } 7.41 \text { year-old } \\
\text { boy }\end{array}$ & $\begin{array}{l}\text { Food selective } \\
\text { behavior } \\
\text { improved }\end{array}$ & $\begin{array}{l}\text { Case study } \\
\text { without } \\
\text { quantitative } \\
\text { data }\end{array}$ & $\mathrm{N} / \mathrm{R}$ & 10 months \\
\hline 2012 & $\begin{array}{l}\text { Liu \& } \\
\text { Chen }\end{array}$ & $\begin{array}{l}\text { Quanzhou city, } \\
\text { Fujian province/ } \\
\text { South-eastern } \\
\text { China }\end{array}$ & $\begin{array}{l}\text { No validated } \\
\text { measurement } \\
\text { tool }\end{array}$ & $\begin{array}{l}\mathrm{N}=41 \\
36 \text { boys and } 5 \text { girls } \\
\text { (Age range: } 2.5-5 \\
\text { years) }\end{array}$ & $\begin{array}{l}\text { Language } \\
\text { ability } \\
\text { improved }\end{array}$ & $\begin{array}{l}\text { Within } \\
\text { group } \\
\text { design }\end{array}$ & $\begin{array}{l}\text { Chinese } \\
\text { Classification } \\
\text { of Mental } \\
\text { Diseases, } 3 \text { rd } \\
\text { (CCMD-3, } \\
\text { Chen, 2002), }\end{array}$ & 1 year \\
\hline 2012 & $\begin{array}{l}\text { Yang, Zhu } \\
\& \text { Cao }\end{array}$ & NR & $\begin{array}{l}\text { Child: } \\
\text { Behavior } \\
\text { observation }\end{array}$ & one 5 year-old boy & $\begin{array}{l}\text { Seat-leaving } \\
\text { behavior } \\
\text { reduced }\end{array}$ & $\begin{array}{l}\text { Single case } \\
\text { design, } \\
\text { ABAB } \\
\text { reversal } \\
\text { design } \\
\end{array}$ & $\mathrm{N} / \mathrm{R}$ & 7 weeks \\
\hline
\end{tabular}




\begin{tabular}{|c|c|c|c|c|c|c|c|c|}
\hline 2011 & Sun \& Wei & $\begin{array}{l}\text { Beijing/ } \\
\text { Northern China }\end{array}$ & $\begin{array}{l}\text { Child: } \\
\text { Behavior } \\
\text { observations } \\
\text { (include } \\
\text { FBA) }\end{array}$ & $\begin{array}{l}11 \text { year-old boy and } \\
\text { a } 12 \text { year-old boy }\end{array}$ & $\begin{array}{l}\text { Self-injury } \\
\text { behavior } \\
\text { reduced }\end{array}$ & $\begin{array}{l}\text { single case } \\
\text { design, } A B \\
\text { design }\end{array}$ & $\begin{array}{l}\text { An } \\
\text { authorative } \\
\text { hospital }\end{array}$ & $\begin{array}{l}\text { One with } \\
22 \text { days } \\
\text { and the } \\
\text { other } 14 \\
\text { days }\end{array}$ \\
\hline 2010 & $\begin{array}{l}\text { Xiong et } \\
\text { al. }\end{array}$ & $\begin{array}{l}\text { Beijing/ } \\
\text { Northern China }\end{array}$ & $\begin{array}{l}\text { Parents: } \\
\text { Hospital } \\
\text { Anxiety and } \\
\text { Depression } \\
\text { Scale } \\
\text { (HADS, } \\
\text { Barczak, } \\
\text { Kane, } \\
\text { Andrews, } \\
\text { Congdon, } \\
\text { Clay, \& } \\
\text { Betts, 1988); } \\
\text { Child: ABC } \\
\text { scale }\end{array}$ & $\begin{array}{l}\mathrm{N}=76 \\
\text { Gener and age } \\
\text { unkown }\end{array}$ & $\begin{array}{l}\text { Children's } \\
\text { sense ability, } \\
\text { social ability, } \\
\text { movement } \\
\text { ability, speech } \\
\text { ability and } \\
\text { self-care } \\
\text { ability } \\
\text { improved } \\
\text { significantly; } \\
\text { Mothers' } \\
\text { anxiety and } \\
\text { depression not } \\
\text { improve }\end{array}$ & $\begin{array}{l}\text { Experiment } \\
\text { al design: } \\
\text { Within } \\
\text { group } \\
\text { design }\end{array}$ & DSM-III & 10 weeks \\
\hline 2008 & Wang & $\begin{array}{l}\text { Shenyang city, } \\
\text { Liaoning } \\
\text { province } \\
\text { /North-eastern } \\
\text { China }\end{array}$ & $\begin{array}{l}\text { Child: PEP- } \\
\text { R (Schopler, } \\
\text { Reichler, } \\
\text { Bashford, } \\
\text { Lansing, \& } \\
\text { Marcus, } \\
\text { 1990), } \\
\text { CARS }\end{array}$ & $\begin{array}{l}\mathrm{N}=27 \\
15 \text { parents (average } \\
\text { age: Father's, } 34.53 \\
\text { years old; mother's, } \\
33.4 \text { years old) in the } \\
\text { experiment group; } \\
12 \text { families in the } \\
\text { control group } \\
\text { (average age: } \\
\text { father's, } 34.92 ;\end{array}$ & $\begin{array}{l}\text { More } \\
\text { appropriated } \\
\text { responses to } \\
\text { child's } \\
\text { behavior; } \\
\text { More } \\
\text { acceptable of } \\
\text { child; More } \\
\text { engagement } \\
\text { play with } \\
\text { children }\end{array}$ & $\begin{array}{l}\text { Experiment } \\
\text { al design: } \\
\text { Within } \\
\text { group } \\
\text { design and } \\
\text { between- } \\
\text { group } \\
\text { design }\end{array}$ & $\mathrm{N} / \mathrm{R}$ & $\begin{array}{l}20 \mathrm{~h} \\
\text { across a } \\
\text { span of } \\
\text { four weeks } \\
(16 \mathrm{hrs} \\
\text { group } \\
\text { training } \\
\text { and } 4 \text { hrs } \\
\text { individual } \\
\text { home } \\
\text { visits) }\end{array}$ \\
\hline
\end{tabular}




\begin{tabular}{|c|c|c|c|c|c|c|c|c|}
\hline & & & & $\begin{array}{l}\text { mothers } 33.5 \text { years } \\
\text { old) } \\
\text { Child: } 15 \text { children } \\
\text { (average age: } 67.3 \\
\text { months) in } \\
\text { experiment and } 12 \\
\text { children (average } \\
\text { age: } 69.3 \text { months) in } \\
\text { control group }\end{array}$ & & & & \\
\hline 2008 & Zou et al. & $\begin{array}{l}\text { Nangjing city, } \\
\text { Jiangsu } \\
\text { province/Easter } \\
\text { n China }\end{array}$ & $\begin{array}{l}\text { Child: } \\
\text { CARS; } \\
\text { Portage Early } \\
\text { Education } \\
\text { Behavior } \\
\text { Checklist } \\
\text { (Bluma, } \\
\text { 1992) }\end{array}$ & $\begin{array}{l}\mathrm{N}=135 \\
51 \text { children trained } \\
\text { by parents ( } 44 \text { boys } \\
\text { and } 5 \text { girls, age } \\
\text { range: } 23-106 \\
\text { months, } 52+-17) \text {; } \\
79 \text { children }(68 \text { boys } \\
\text { and } 11 \text { girls, age } \\
\text { range: } 24-116 \\
\text { months, } 37+-6) \\
\text { trained by } \\
\text { professionals }\end{array}$ & $\begin{array}{l}\text { Parents' DTT } \\
\text { implementatio } \\
\text { n strategies } \\
\text { improved } \\
\text { after } \\
\text { professional } \\
\text { training; } \\
\text { Children from } \\
\text { both groups } \\
\text { showed } \\
\text { changes in } \\
\text { socialization, } \\
\text { self-help, } \\
\text { language, } \\
\text { cognitive, and } \\
\text { motor } \\
\text { development. }\end{array}$ & $\begin{array}{l}\text { Within } \\
\text { group } \\
\text { design and } \\
\text { between- } \\
\text { group } \\
\text { design }\end{array}$ & DSM-IV & 3 months \\
\hline 2007 & $\begin{array}{l}\text { Shi, Yu, } \\
\text { Guo \& Li }\end{array}$ & $\begin{array}{l}\text { Tianjin/Norther } \\
\text { n China }\end{array}$ & $\begin{array}{l}\text { Child: Gesell } \\
\text { Development } \\
\text { Assessment } \\
\text { (Gesell, } \\
\text { 1925), CARS }\end{array}$ & $\begin{array}{l}\mathrm{N}=85 \\
75 \text { boys and } 10 \text { girls } \\
\text { (Average: } 3.67 \text { years } \\
\text { old) }\end{array}$ & $\begin{array}{l}60 \% \text { of } \\
\text { children } \\
\text { entered } \\
\text { mainstream } \\
\text { school. }\end{array}$ & $\begin{array}{l}\text { Within } \\
\text { group } \\
\text { design }\end{array}$ & DSM-IV & $\begin{array}{l}3-12 \\
\text { months } \\
\text { depends } \\
\text { on }\end{array}$ \\
\hline
\end{tabular}




\begin{tabular}{|c|c|c|c|c|c|c|c|c|}
\hline & & & & & & & & $\begin{array}{l}\text { individuals } \\
\text { ability }\end{array}$ \\
\hline 2006 & Guo & $\begin{array}{l}\text { Beijing/ } \\
\text { Northern China }\end{array}$ & NR & $\begin{array}{l}\mathrm{N}=129 \text { parents } \\
\text { Gender and age } \\
\text { unkown }\end{array}$ & $\begin{array}{l}\text { Better } \\
\text { understanding } \\
\text { of child's } \\
\text { problematic } \\
\text { behaviors; } \\
\text { better ways of } \\
\text { educating } \\
\text { children; } \\
\text { More } \\
\text { cooperative } \\
\text { with } \\
\text { professionals }\end{array}$ & $\begin{array}{l}\text { Empirical } \\
\text { study } \\
\text { witout } \\
\text { quantitative } \\
\text { data }\end{array}$ & $\mathrm{N} / \mathrm{R}$ & 3 months \\
\hline 2006 & $\begin{array}{l}\text { Guo, Liu } \\
\& \mathrm{Du} *\end{array}$ & $\begin{array}{l}\text { Shenyang city, } \\
\text { Liaoning } \\
\text { province/North- } \\
\text { eastern China }\end{array}$ & $\begin{array}{l}\text { Children's } \\
\text { exam grades } \\
\text { reported by } \\
\text { parents }\end{array}$ & $\begin{array}{l}\mathrm{N}=64 \\
51 \text { boys and } 13 \text { girls } \\
\text { (average age } 10.6 \\
\text { years old) }\end{array}$ & $\begin{array}{l}\text { language, } \\
\text { social } \\
\text { communicatio } \\
\text { n, social } \\
\text { recoginition } \\
\text { improved }\end{array}$ & $\begin{array}{l}\text { Qualitative } \\
\text { interview }\end{array}$ & $\begin{array}{l}\text { Chinese } \\
\text { Classification } \\
\text { of Mental } \\
\text { Diseases, } 3 \text { rd } \\
\text { (CCMD-3, } \\
\text { Chen, 2002) }\end{array}$ & $\begin{array}{l}\text { Follow up } \\
\text { study on } \\
\text { ABA } \\
\text { training } \\
\text { for 2-4 } \\
\text { years }\end{array}$ \\
\hline
\end{tabular}

* Title of articles was translated by the first author because articles do not have an Enligsh title.

**Behavior observations are typically using single-system designs (Hichcock, Kratochwill, \& Chezan, 2015). Direct observation of ABC data (antecient, A; behavior, B and consequence, C) and Funcitonal Behaivour Assessment (FBA) were commonly types of behavior observations as of reported in this table. 
Table 3 Quality of research of single case design studies

\begin{tabular}{|c|c|c|c|c|c|c|}
\hline Year & Authors & Study design & (a) & (b) & (c) & $\begin{array}{c}\text { Study Rating Determinants for Single-Case } \\
\text { Designs }\end{array}$ \\
\hline 2017 & $\begin{array}{l}\text { Lee, Feng, Xu \& } \\
\text { Jin }\end{array}$ & $\begin{array}{l}\text { Multiple probe } \\
\text { design }\end{array}$ & $\checkmark$ & $\checkmark$ & $\checkmark$ & $\begin{array}{l}\text { Meets WWC Pilot Single-Case Design } \\
\text { Standards without Reservations }\end{array}$ \\
\hline 2017 & $\begin{array}{l}\text { Xu, Wang, Lee \& } \\
\text { Luke }\end{array}$ & $\begin{array}{c}\text { Changing criterion } \\
\text { design }\end{array}$ & $\checkmark$ & $\checkmark$ & $x$ & $\begin{array}{c}\text { Does Not Meet WWC Pilot Single-Case } \\
\text { Design Standards }\end{array}$ \\
\hline 2017 & Zhen \& Li & ABA design & $\checkmark$ & $x$ & $x$ & $\begin{array}{c}\text { Does Not Meet WWC Pilot Single-Case } \\
\text { Design Standards }\end{array}$ \\
\hline 2017 & Shen & $\mathrm{ABAB}$ design & $\checkmark$ & $x$ & $\checkmark$ & $\begin{array}{l}\text { Meets WWC Pilot Single-Case Design } \\
\text { Standards without Reservations }\end{array}$ \\
\hline 2016 & Hu, Chen \& Zhen & $\mathrm{ABAB}$ design & $\checkmark$ & $\checkmark$ & With reservation & $\begin{array}{l}\text { Meets WWC Pilot Single-Case Design } \\
\text { Standards with Reservations }\end{array}$ \\
\hline 2016 & $\begin{array}{l}\mathrm{Hu}, \text { Liu, Fan \& } \\
\text { Zhen }\end{array}$ & $\begin{array}{l}\text { Multiple baseline } \\
\text { design }\end{array}$ & $\checkmark$ & $\checkmark$ & $\checkmark$ & $\begin{array}{l}\text { Meets WWC Pilot Single-Case Design } \\
\text { Standards without Reservations }\end{array}$ \\
\hline 2016 & Wang & ABA design & $\checkmark$ & $x$ & $x$ & $\begin{array}{c}\text { Does Not Meet WWC Pilot Single-Case } \\
\text { Design Standards }\end{array}$ \\
\hline 2016 & Huo, Liu \& Hu & ABA design & $\checkmark$ & $\checkmark$ & $x$ & $\begin{array}{l}\text { Does Not Meet WWC Pilot Single-Case } \\
\text { Design Standards }\end{array}$ \\
\hline
\end{tabular}




\begin{tabular}{|c|c|c|c|c|c|c|}
\hline \multirow[b]{2}{*}{2016} & \multirow[b]{2}{*}{ Qian } & \multirow[b]{2}{*}{ ABA design } & \\
\hline & & & $\checkmark$ & $x$ & $x$ & $\begin{array}{c}\text { Does Not Meet WWC Pilot Single-Case } \\
\text { Design Standards }\end{array}$ \\
\hline 2015 & Hu et al. & $\begin{array}{l}\text { Multiple probe } \\
\text { design }\end{array}$ & $\checkmark$ & $x$ & $x$ & $\begin{array}{c}\text { Does Not Meet WWC Pilot Single-Case } \\
\text { Design Standards }\end{array}$ \\
\hline 2015 & Xiao \& Yu & ABA design & $\checkmark$ & $\checkmark$ & $x$ & $\begin{array}{c}\text { Does Not Meet WWC Pilot Single-Case } \\
\text { Design Standards }\end{array}$ \\
\hline 2014 & $\mathrm{Hu} \&$ Fan & $\begin{array}{l}\text { Multiple baseline } \\
\text { design }\end{array}$ & $\checkmark$ & $\checkmark$ & $\checkmark$ & $\begin{array}{l}\text { Meets WWC Pilot Single-Case Design } \\
\text { Standards without Reservations }\end{array}$ \\
\hline 2012 & Yang, Zhu \& Cao & $\mathrm{ABAB}$ design & $\checkmark$ & $\checkmark$ & With reservation & $\begin{array}{l}\text { Meets WWC Pilot Single-Case Design } \\
\text { Standards with Reservations }\end{array}$ \\
\hline 2011 & Sun \& Wei & $\mathrm{AB}$ design & $\checkmark$ & $x$ & $x$ & $\begin{array}{c}\text { Does Not Meet WWC Pilot Single-Case } \\
\text { Design Standards }\end{array}$ \\
\hline
\end{tabular}


Appendix 1: Search terms of reviews

\begin{tabular}{|c|c|c|c|}
\hline No. & Databases & Search terms & Records \\
\hline 1 & ERIC & 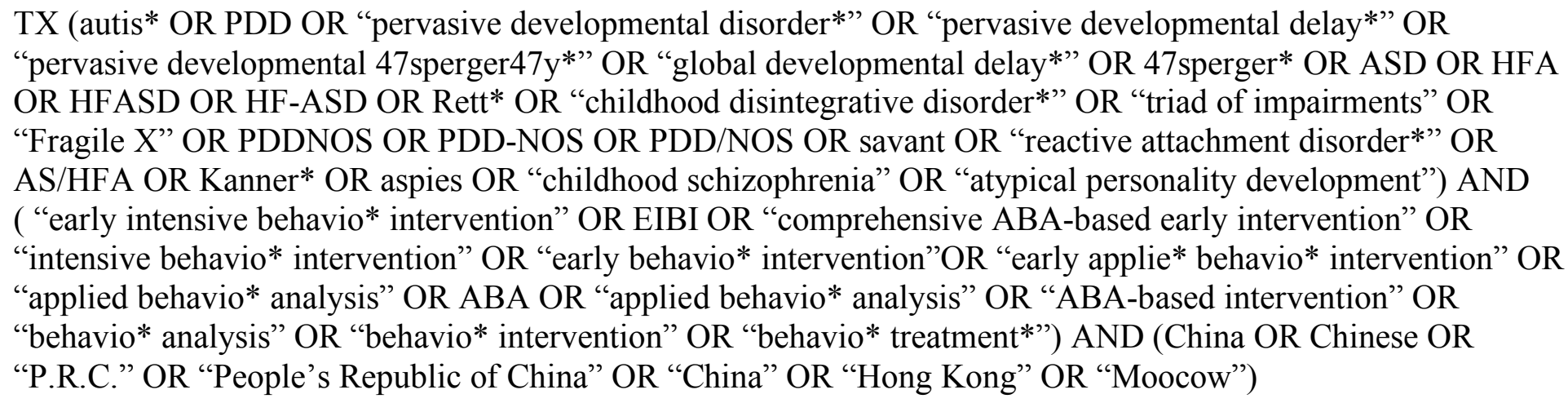 & 4 \\
\hline 2 & $\begin{array}{l}\text { Web of } \\
\text { Science }\end{array}$ & 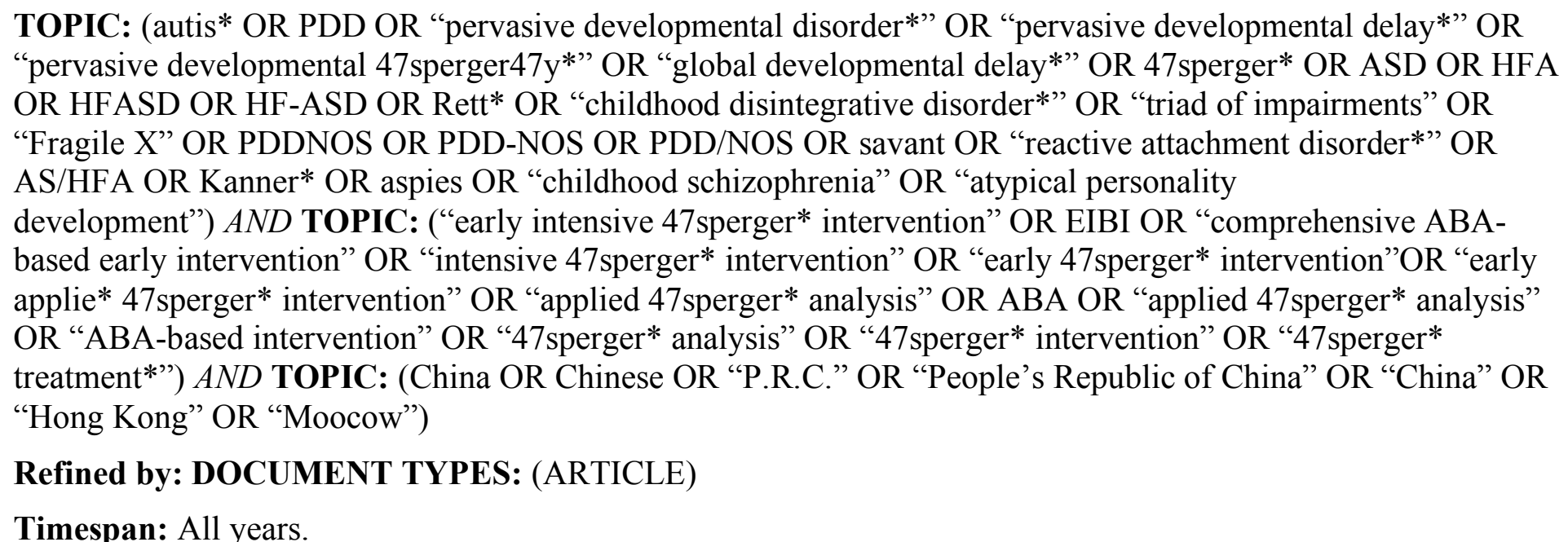 & 18 \\
\hline
\end{tabular}




\begin{tabular}{|c|c|c|c|}
\hline 3 & $\begin{array}{c}\text { ProQuest } \\
\text { Education } \\
\text { Journals }\end{array}$ & $\begin{array}{l}\text { AB(autis* OR PDD OR "pervasive developmental disorder*” OR "pervasive developmental delay*” OR } \\
\text { "pervasive developmental 48sperger48y*" OR "global developmental delay*" OR 48sperger* OR ASD OR HFA } \\
\text { OR HFASD OR HF-ASD OR Rett* OR "childhood disintegrative disorder" OR "triad of impairments" OR } \\
\text { "Fragile X" OR PDDNOS OR PDD-NOS OR PDD/NOS OR savant OR "reactive attachment disorder*" OR } \\
\text { AS/HFA OR Kanner* OR aspies OR "childhood schizophrenia" OR "atypical personality development") AND } \\
\text { ("early intensive behavio* intervention" OR EIBI OR "comprehensive ABA-based early intervention" OR } \\
\text { "intensive behavio* intervention" OR "early behavio* intervention" OR "early applie* behavio* intervention" } \\
\text { OR "applied behavio* analysis" OR ABA OR "applied behavio* analysis" OR "ABA-based intervention" OR } \\
\text { "behavio* analysis" OR "behavio* intervention" OR "behavio* treatment"”) AND (China OR Chinese OR } \\
\text { "P.R.C." OR "People's Republic of China" OR "China" OR "Hong Kong" OR "Moocow") }\end{array}$ & 86 \\
\hline 4 & SCOPUS & 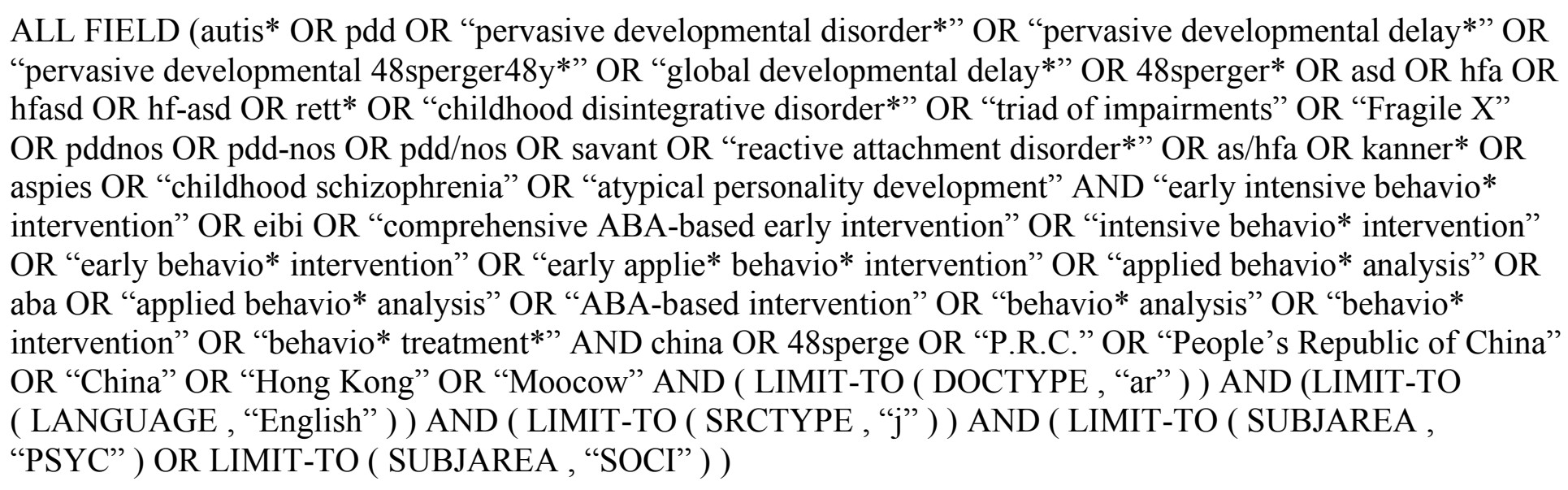 & 38 \\
\hline 5 & PubMed & $\begin{array}{l}\text { (((autis*[Title/Abstract] OR PDD[Title/Abstract] OR “pervasive developmental } \\
\text { disorder*”[Title/Abstract] OR “pervasive developmental delay*”[Title/Abstract] OR “pervasive } \\
\text { developmental 48sperger48y*”[Title/Abstract] OR "global developmental delay*”[Title/Abstract] OR } \\
\text { 48sperger*[Title/Abstract] OR ASD[Title/Abstract] OR HFA[Title/Abstract] OR HFASD[Title/Abstract] } \\
\text { OR HF-ASD[Title/Abstract] OR Rett*[Title/Abstract] OR “childhood disintegrative } \\
\text { disorder*”[Title/Abstract] OR “triad of impairments”[Title/Abstract] OR "Fragile X”[Title/Abstract] OR } \\
\text { PDDNOS[Title/Abstract] OR PDD-NOS[Title/Abstract] OR PDD/NOS[Title/Abstract] OR } \\
\text { savant[Title/Abstract] OR "reactive attachment disorder*”[Title/Abstract] OR AS/HFA[Title/Abstract] }\end{array}$ & 15 \\
\hline
\end{tabular}




\begin{tabular}{|c|c|c|c|}
\hline & & 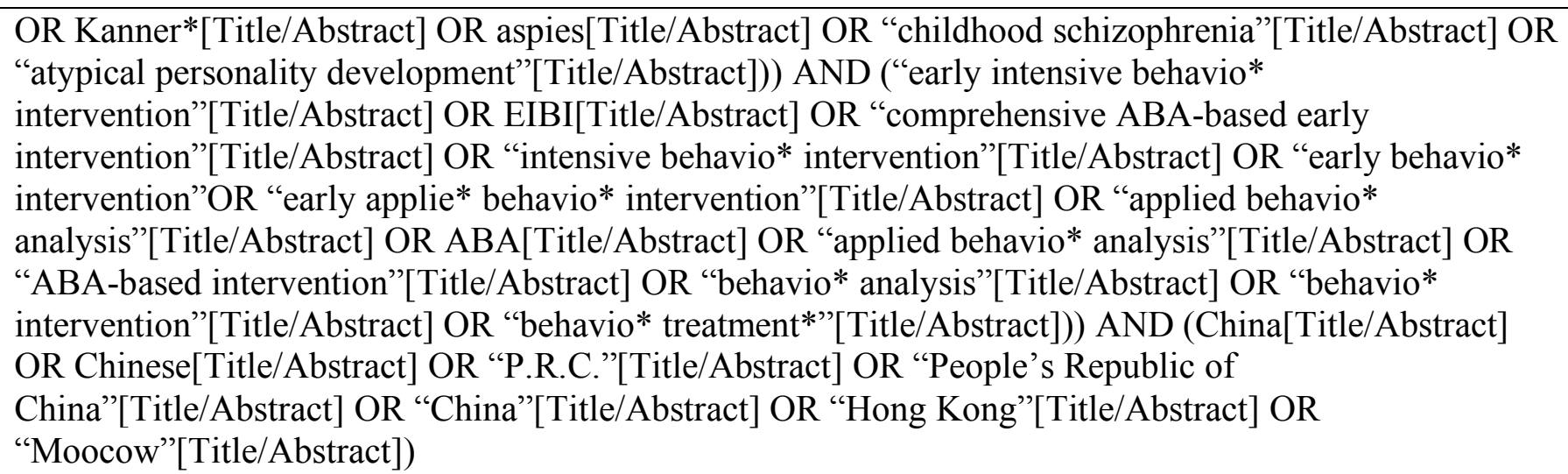 & \\
\hline 6 & $\begin{array}{c}\text { 16 Journal } \\
\text { Search* }\end{array}$ & All field (autism AND China) & 112 \\
\hline 7 & $\begin{array}{l}\text { CKNI } \\
\text { (知网) }\end{array}$ & Title (自闭症 OR 孤独症) and (应用行为分析 OR ABA) & 653 \\
\hline 8 & $\begin{array}{c}\text { VIP } \\
\text { (维普) }\end{array}$ & 任意字段 (自闭症 OR 孤独症) and (应用行为分析) & 154 \\
\hline 9 & $\begin{array}{c}\text { WANFANG } \\
\text { DATA } \\
\text { (万方 })\end{array}$ & 摘要(自闭症 OR 孤独症) and (应用行为分析) & 82 \\
\hline Total & & & 1,162 \\
\hline
\end{tabular}

Note: No.1-No.5 are terms for English language databases; No. 6 are terms for journal searches; No.7-No.9 are terms for Chinese language databases.

*16 journals including: including Journal of Applied Behavior Analysis, Journal of Early and Intensive Behavior Intervention, Analysis of Verbal Behavior, Journal of the Experimental Analysis of Behavior, Behavior Analysis in Practice, European Journal of Behavior Analysis, Behavior analyst, Behavioral Interventions, Behavior Analyst Today, Journal of Positive Behavior Interventions, and Behavior and Philosophy,. Behavior Modification, Research in Autism Spectrum Disorder, Research in Developmental Disabilities, Research and Practice for Persons with Severe Disabilities, Journal of Autism and Developmental Disorder. 
